Bull. Fac. Agric., Cairo Univ., 62: 1-13 (2011)

\title{
A STUDY OF SOME SOCIAL VARIABLES THAT DETERMINE WHEAT CROP PRODUCTION IN BEHIRA AND ASSUIT GOVERNORATES.
}

(Received: 27.11.2010)

\author{
By \\ S. M. Nasrat and H. M. Farag \\ Rural Community Research Department, Agricultural Extension and Rural Development \\ Research Institute, Agricultural Research Center,Giza,Egypt
}

\begin{abstract}
This study deals with some social variables that influence wheat crop production in both Governorates chosen, Al -Behira and Assuit. The main objective of this study was to establish the difference between average wheat production per feddan in both Governorates. In addition to determine, the effect of some social variables on (WCP) and identify farmers suggestion in regard of (NCP) increase. The data gathered under the title: Self - reliance of wheat production" :A study of the determinants factors affecting the WCP in Egypt presented to the Ministry of Agriculture and Land Reclamation-Rural Community Department, Extension Research Center.

The data were collected from two districts of each governorate and two villages from each district through personal interview. The sample consisted of 230 cases. Frequencies, percentages, means, mode, T-test, simple correlation coefficient and Chi-square were used as statistical techniques .

The most important results of the study could be summarized as follows:

Related to $\mathrm{T}$ test ,there are significant differences between the two governorates regarding average wheat crop production per feddan.

According to simple correlation coefficient, there was a negative relationship between wheat crop production per feddan and the following social variables: farmer's age, wife's age and education, besides positive relationships with the number of children and family size.

Concerning Chi-square there were significant relationships between wheat crop production per feddan and farmer's satisfaction upon delivery price (past and current prices), profit and seed prices.

The most important factors that determine wheat crop production were: farmer's age, wife's age, number of children, family size, satisfaction upon wheat revenue, seed prices and delivery prices (past and current prices).

The most important suggestions from the farmers point of view to increase productivity were to provide fertilizers at reasonable prices, representing about $31.7 \%$ of interviewed farmers.
\end{abstract}

Key words: Grop production, social variables, wheat. 


\author{
دراسة لبعض المتغيرات الاجتماعية المحددة لإنتاج محصول القمح \\ لمزارعى بعض قرى محافظتى البحيرة وأسيوط الأناج \\ سونيا محيي الدين نصرت ـ حنان مكرم فرج
}

م عهد بحوث الارشاد الزراعي والتنمية الريفيةـ مركز البحوث الزراعيةـ الجيزة ـ مصر

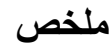

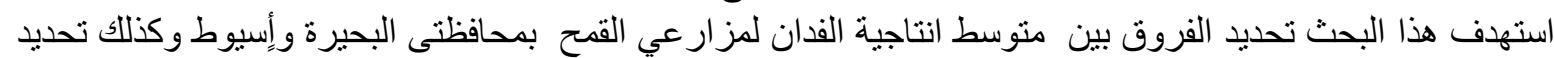

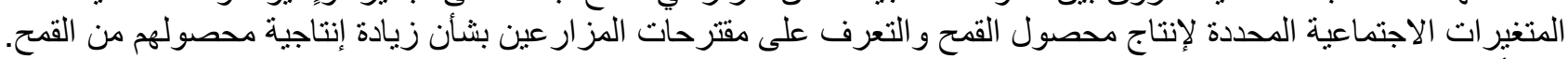

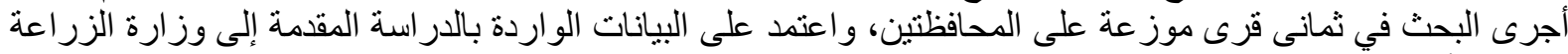

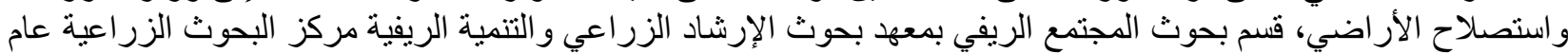

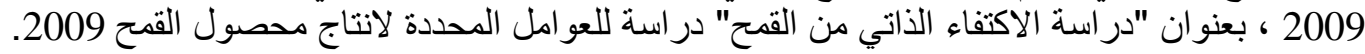

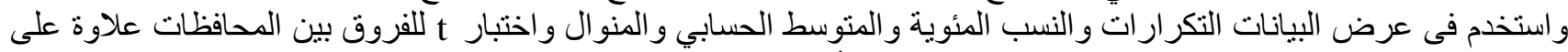

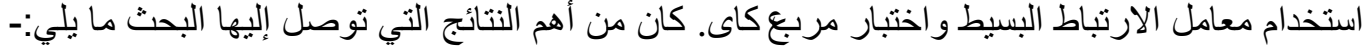

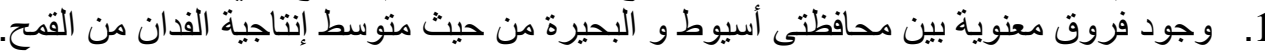

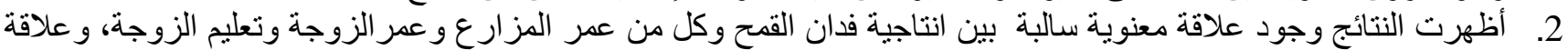

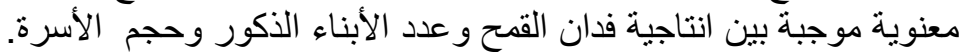

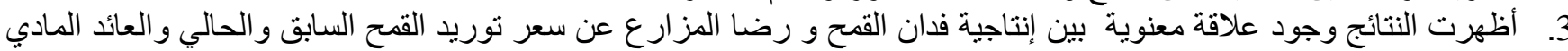

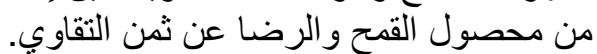

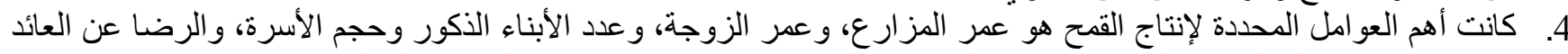

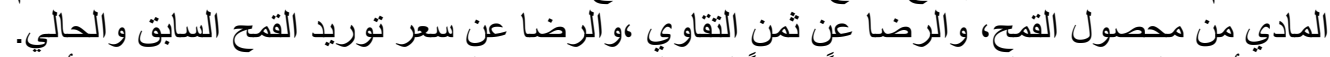

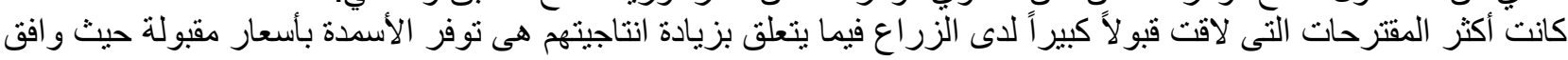

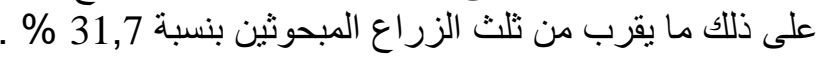

الزيادة المتوقعة فى الاستهلاك مما ينتج عنه زيادة فى صى

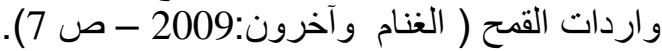

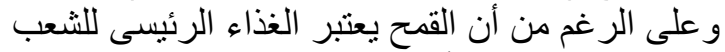

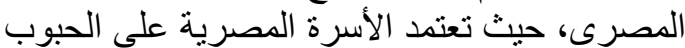

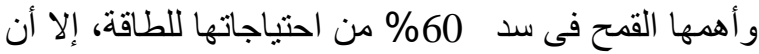

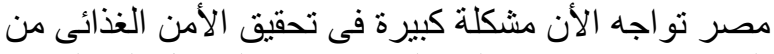

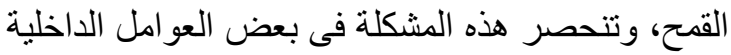

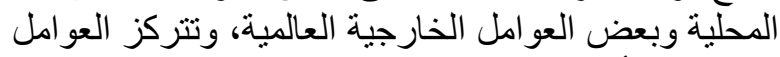

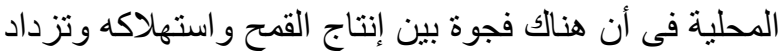

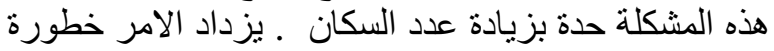

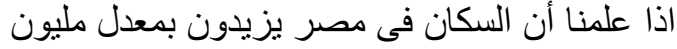

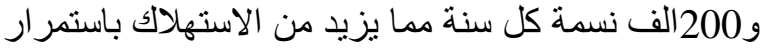
يو اجه القطاع الزراء اعي بمصر مجمو عة من المعوقات

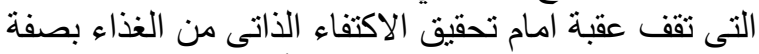

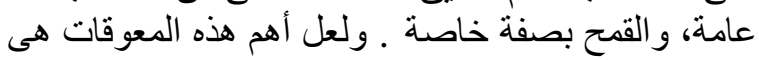

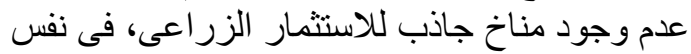

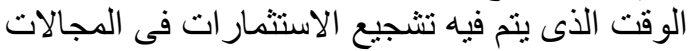

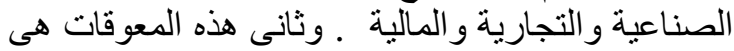
محدودية الرقعة الزراعية الصالحة والية والجيدة للاستخدام

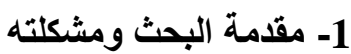

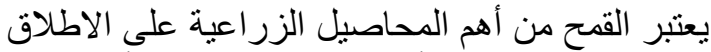

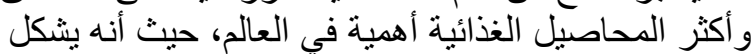

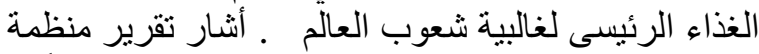

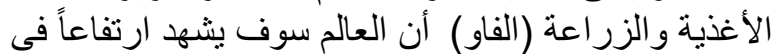

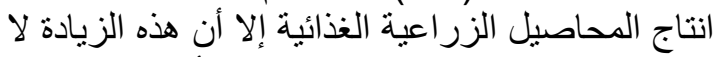

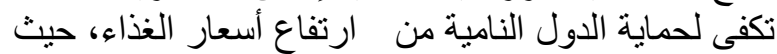

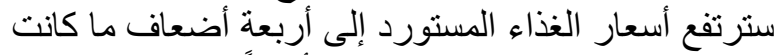

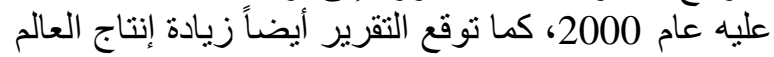

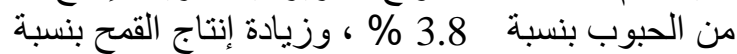

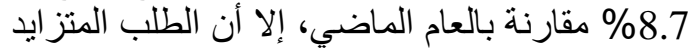
و وارتفاع تكلفة الانتاج لم تستطع مقاومة ارتفاع الأسعار الأسعار

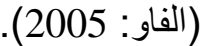

وتحتل مصر المرتبة الثانية بين دول العالم المستوردة

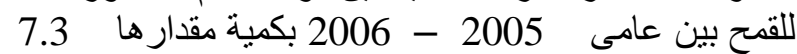

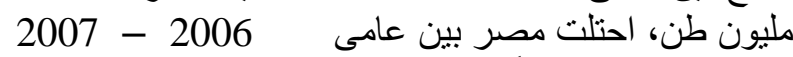

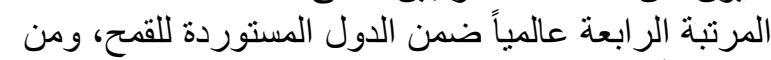

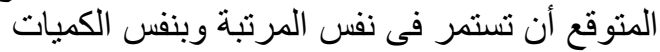

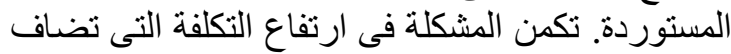

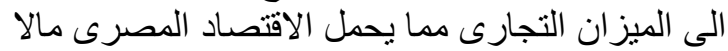
يطيق خاصة فى فروق الأسعار العالمية، بالإضافة إلي الإلي 
ما هى مقترحات المز ار عين لزيادة انتاجية الفدان بمحافظتي

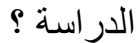

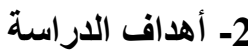

من واقع مشكلة الدراسة التى تم تحديدها أمكن تلخيص التيص

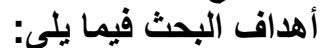

تحديد الفروق بين منوسط البحت التاجية الفدان لمزارعي القمح بمحافظتي البحيرة وأسيوط

تحديد المتغيرات الاجتماعية المحددة لانتاجية الفدان

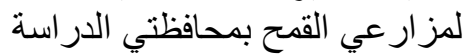
التعرف على مقترحات المز ارعين لزياديادة التتاجية الفدان

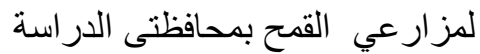

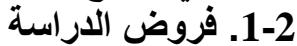

لتحقيق الهدف الاول و الثاني للار اسة تم صياغة

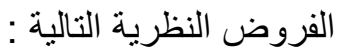

1- نقجد فروق معنوية بين متوسط التتاجية الفدان لمز ارعي القمح في محافظتي البحيرة و وأسيوط.

2- نوجد علاقة معنوية بين منوسط انتاجية الفدان

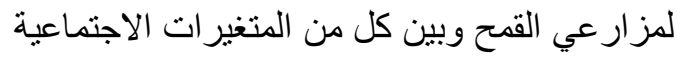

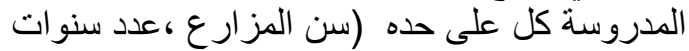

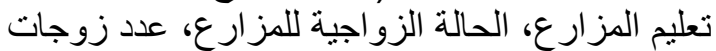

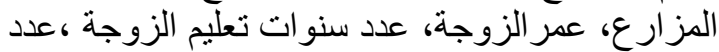

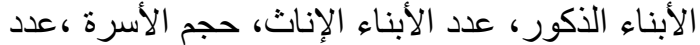

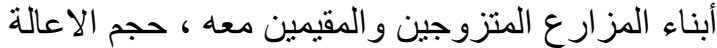

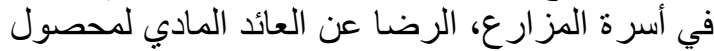

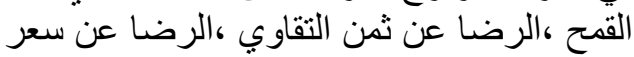

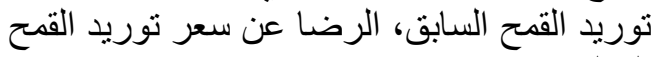

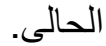

\section{2-2 2-2 خطة البحث}

اعتمد هذا البحث على البيانات الواردة بالدر اسة الزّة

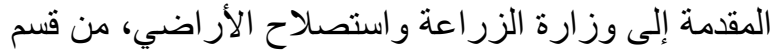

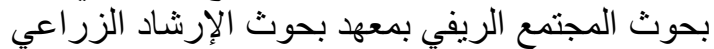

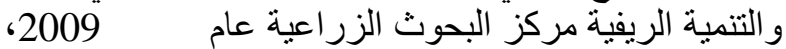

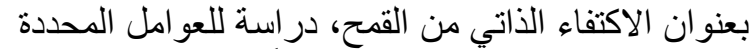

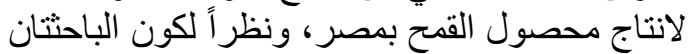

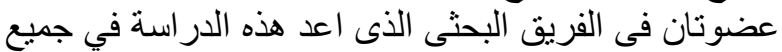

مر احلها، فقد نم اخذ مو افقة الفريق البحثي على الفي القيام بهذا

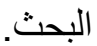
المجال الجغرافى المي تم اختيار محافظة البحيرة حيث تمثل أقل محافظات

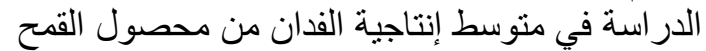

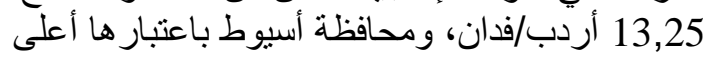

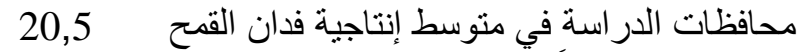

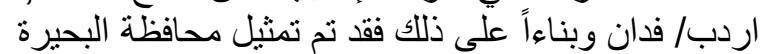

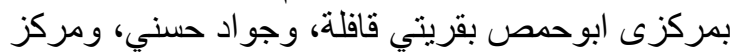
كفر الدوار بقريتى كوم البركة، و السلفون، ومثلّت محافظة ومركة

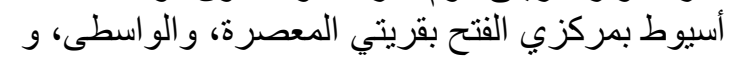

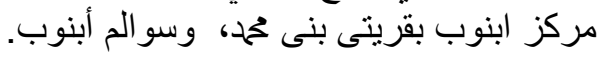

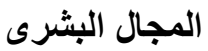
أجرى البحث على عينة قوامها 230 مبحوثاً من
الزراعي يليها في الأهمية ضعف التقنيات المستخدمة

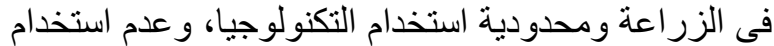
الاساليب الحديثة فى الزر اعة مما يؤدى فى النهاية الى ولى

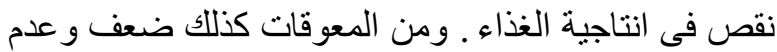

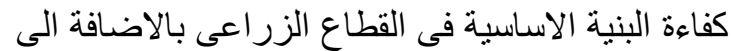

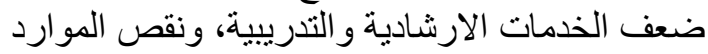

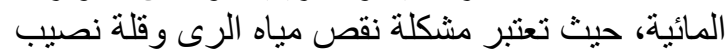

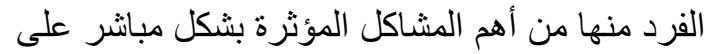

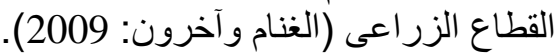

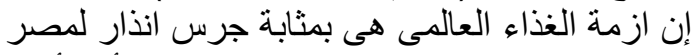

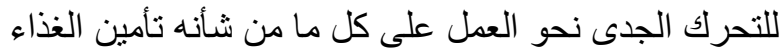

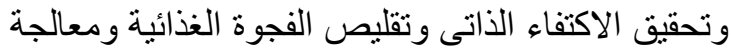

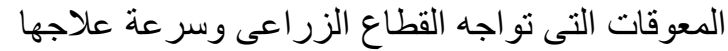

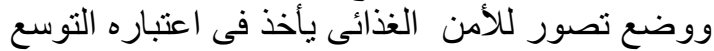

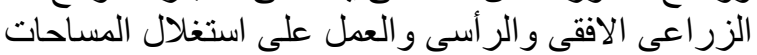

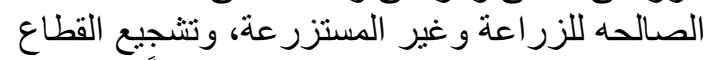

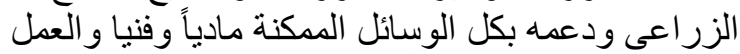
على زيادة الانتاج وصولاً لتحقيق الاكتفاء الذاتى (عمارة: 2002

اما فيما يتعلق بالعو امل الخارجية فيعتبر من أهمها قيام بعض الدول المنتجة للقمح بالاتجاه الى استخدامه في التئ انتاج

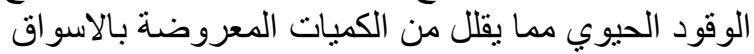

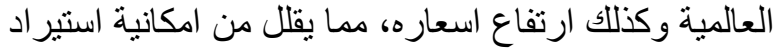

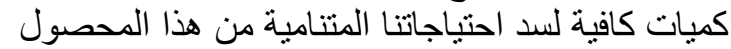

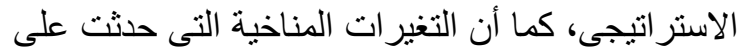

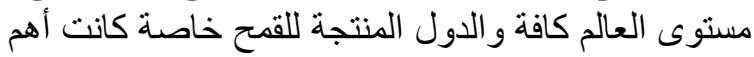

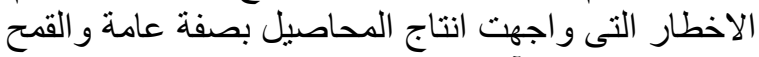

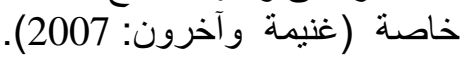
ويرتبط بالاتجاه العام لتحقيق الاكتفاء الذاتى من الغذاء

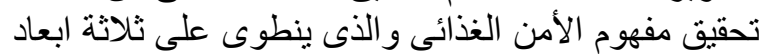

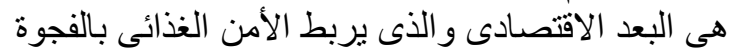

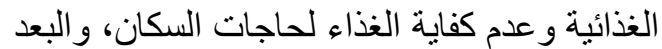

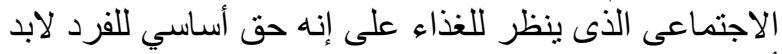

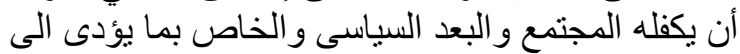

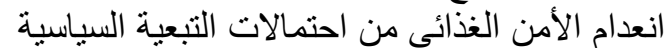

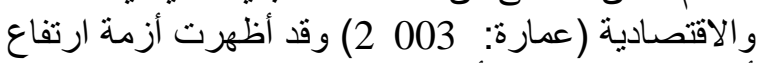

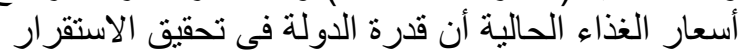

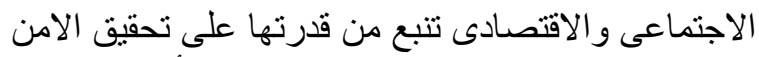

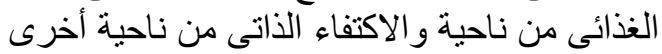

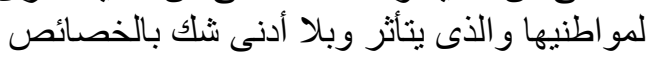

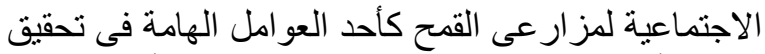

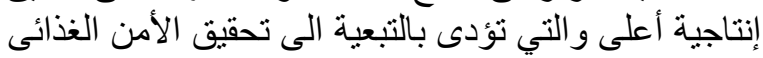

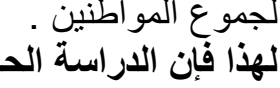
التساؤلات الاتيه: هل هناك فروق معنوية بين التناجيه الفدان لمزارعي القمح

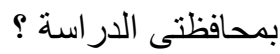

ما هى المتغيرات الاجتماعية المحددة لإنتاجية الفدان لمزارعي القمح بمحافظتي الدراسة ؟ الإنية 
استخدمت الأرقام الأولية في القياس الكمي لمتغيرات

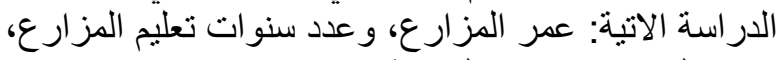

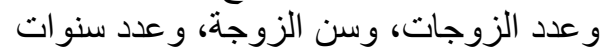
تعليم الزوجة، و عدد الأبناء الذكور، و وعدد الأبناء الإناث،
زر اع القمح بمعدل 110 مبحوثاً بالقرى المدروسة بمحافظة البحيرة، و 120 مبحوثاً بالقرى المدروسة بمحافظة بالفة أسيوط، وفيما يلى توزيع المبحوثين على القرى المدروسة كما هو

موضح بجدول (1)

جدول رقم (1) توزيع أفراد العينة وفقاً لقرى الدراسة

\begin{tabular}{|c|c|c|c|c|c|}
\hline العينه & المختارة & العينه & المختارة & العينه & المدروسظة \\
\hline 30 & قافلة & 60 & مركز ابو حمص & & \\
\hline $\begin{array}{l}30 \\
25 \\
25\end{array}$ & جواد البركنه & 50 & مركز كفر الدوار & 110 & البحيرة \\
\hline \multicolumn{5}{|c|}{110} & جملة البحيرة \\
\hline 30 & المعصره & 60 & مركز الفتح & & \\
\hline $\begin{array}{l}30 \\
30 \\
30\end{array}$ & سوالبى المحلم الوب & 60 & & 120 & أسيوط \\
\hline \multicolumn{5}{|c|}{120} & جملة أسيوط \\
\hline & & & & & جملة العينة \\
\hline
\end{tabular}

وحجم الأسرة، و عدد أبناء المز ارع المتزوجين و المقيمين

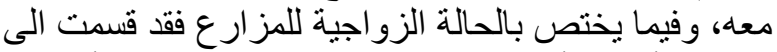

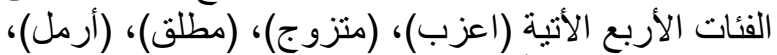

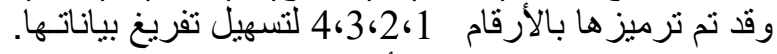

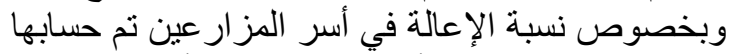

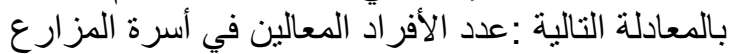

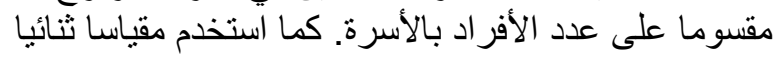

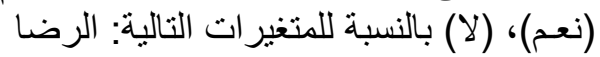

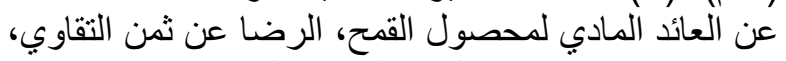

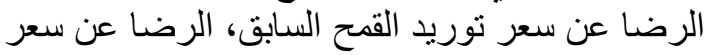

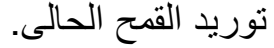

3-2 أدوات التحليل الاحصائى إينى

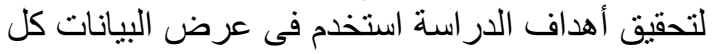

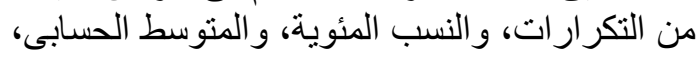

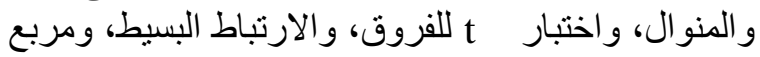
التُعزيف الاجرائى لمتغيرات العوامل الاجتماعية المحددة لإلتاج القمح

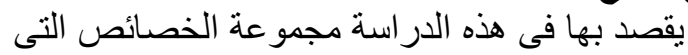
قد تؤثر فى الاتناج بطريقة مباشرة أو غير مباشرة الثرة بعضها

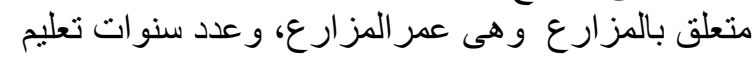

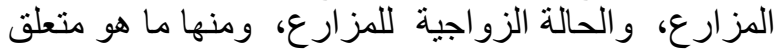

جدول (2) توزيع أفراد العينة حسب متوسط انتاجية الفدان من القمح بمحافظتى الدراسة.

\begin{tabular}{|c|c|c|c|c|c|c|}
\hline \multicolumn{2}{|c|}{ جملة } & \multicolumn{2}{|c|}{ أسيوط } & \multicolumn{2}{|c|}{ البحيزة } & \multirow{2}{*}{ متوسط انتاجية الفدان المحافظة } \\
\hline$\%$ & عدد & $\%$ & عدد & $\%$ & عدد & \\
\hline 20.9 & 48 & 1.7 & 2 & 41.8 & 46 & أقل من 13 اردب \\
\hline 27.8 & 64 & 5.00 & 6 & 52.7 & 58 & من 13 - 15 اردب \\
\hline 24.8 & 80 & 61.7 & 74 & 5.5 & 6 & أكثر من 16 - 18 اردب \\
\hline 16.5 & 38 & 31.6 & 38 & - & - & أكثر من 18 اردب \\
\hline \multicolumn{2}{|c|}{230} & \multicolumn{2}{|c|}{120} & \multicolumn{2}{|c|}{110} & إجمالي حجم العينة \\
\hline \multicolumn{2}{|c|}{230} & \multicolumn{2}{|c|}{20.5} & \multicolumn{2}{|c|}{13.25} & المتوسط الحسابي \\
\hline
\end{tabular}

\section{وصف عينة الاراسة} أولاً: متوسط انتاجية الفدان لمزارعي القمح بمحافظتى

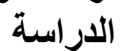

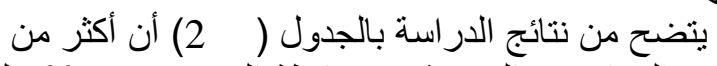

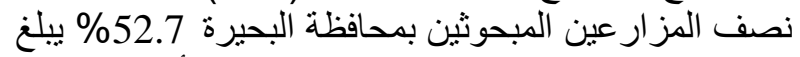

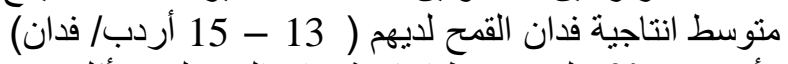

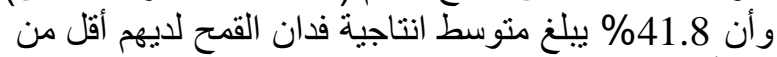

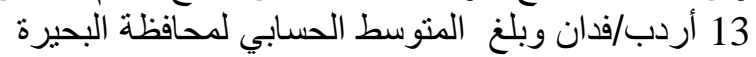

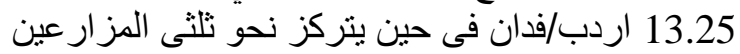

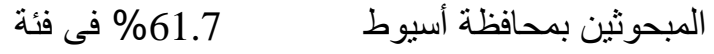

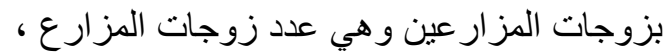

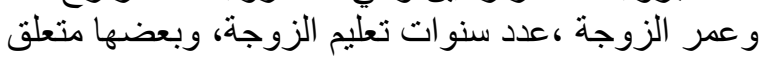

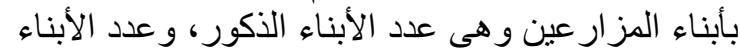

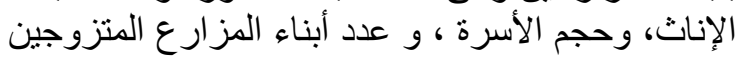

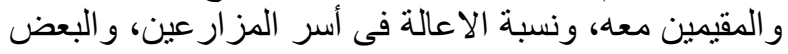

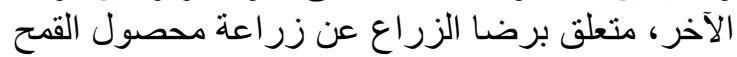

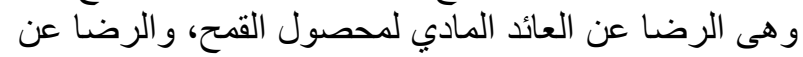

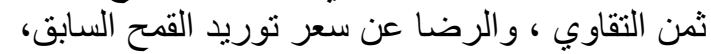

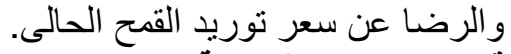

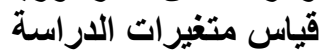


الدراسة بلغ 110 مبحوثاً بنسبة 47.8\% منها 56 مز ار عاً بقرى محافظة البحيرة بنسبة

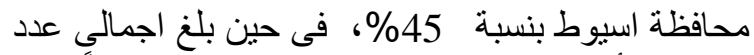

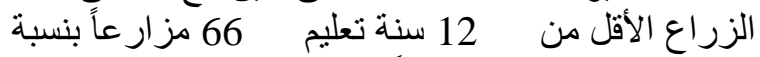

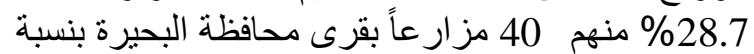

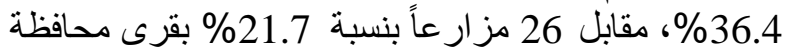

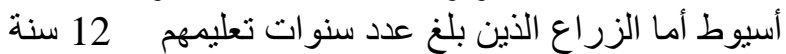

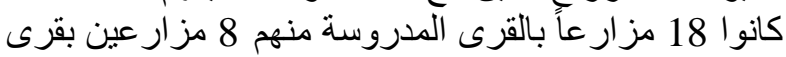

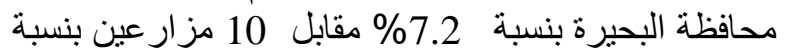
8.3 بقرى محافظة أسيوط.

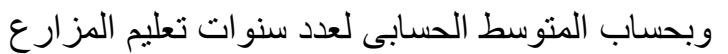

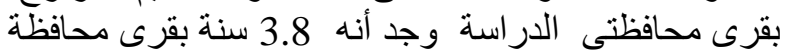
البحيرة مقابل 5.6 سنة بقرى محافظة أسيوط وأنة وأن منو ال

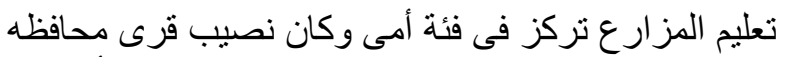

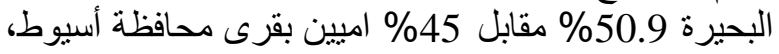

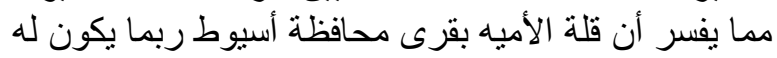

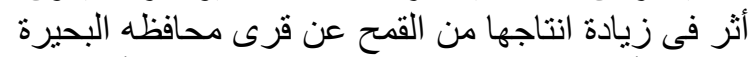

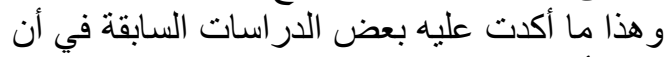

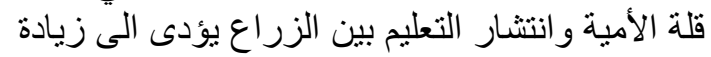
انتاجيتهم. 3- الحالة الزواجية للمزارع

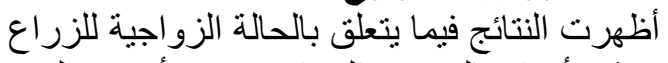

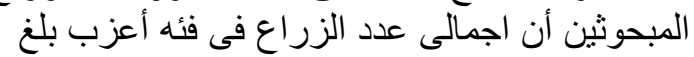

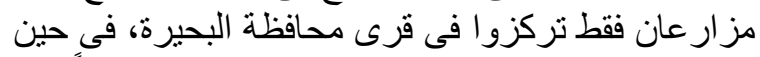

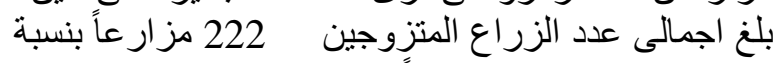

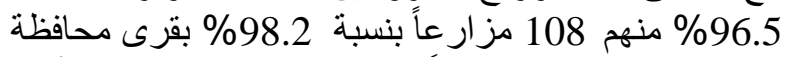

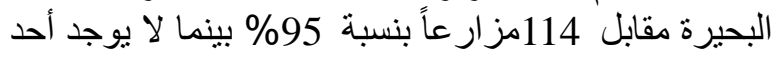

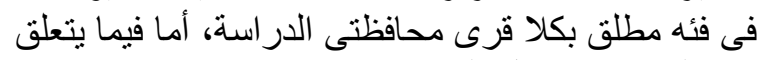

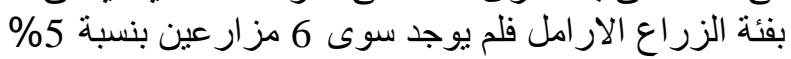

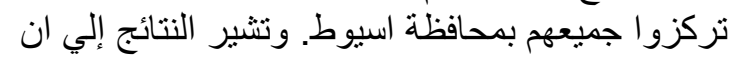

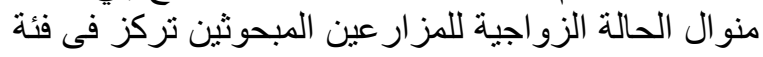

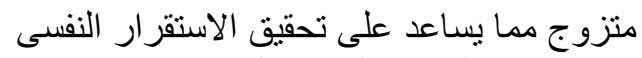

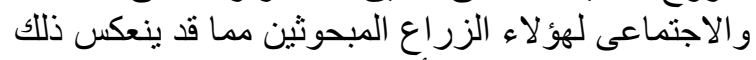

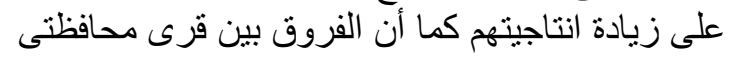

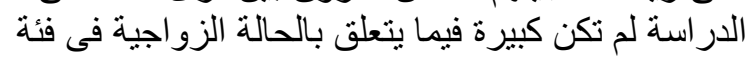

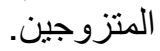

بـ المتغيرات الاجتماعية المتعلقة بزوجات المزارع:-

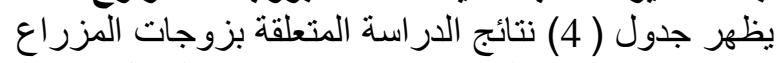

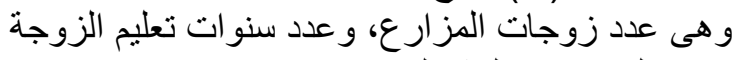
وفيما يلى عرض زوض لهذه النتائج:-

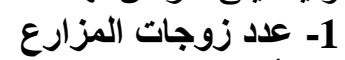

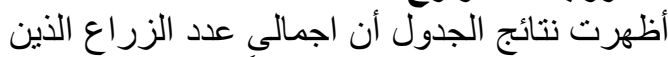

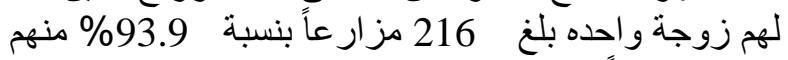

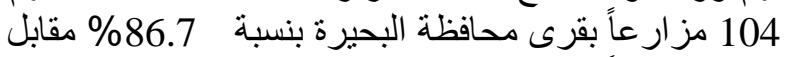

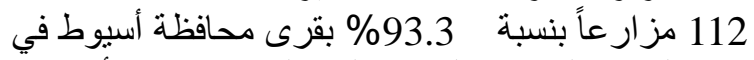

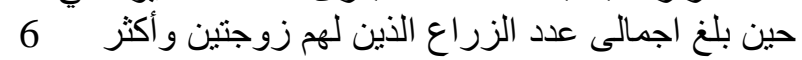

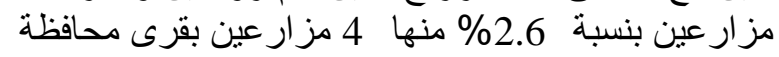

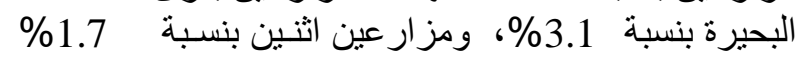
بقرى محافظة اسيوط بينما بلغ اجمالى عدد الزراع لفين الذين
منوسط انتاجية فدان القمح ( 16 - 18 أردب/فوندان) وما

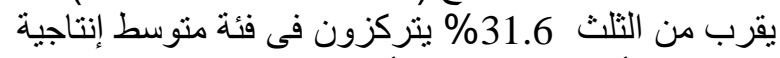

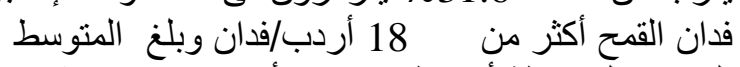

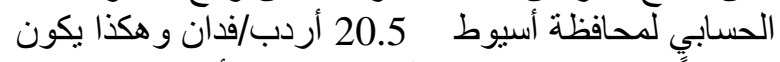
و اضحاً زيادة انتاجية فدان القمح بمحافظة أسيوط عن أنسان محافظة البحيرة .

ثانيا: توزيع أفراد العينة حسب المتغيرات الاجتماعية المدروسة تونيع

تتقسم المتغير ات الاجتماعية المدروسة الى متغير ات

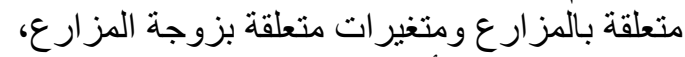

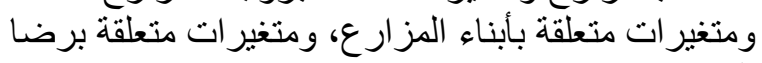

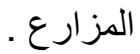

وتوضح نتائج الدر اسة بجدول المتول (3) ما يلي:

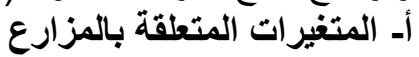

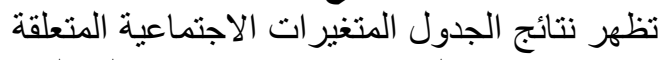

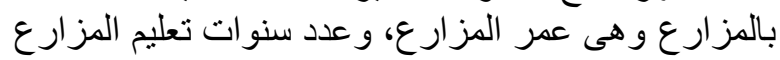

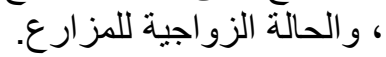

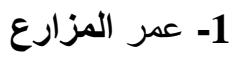

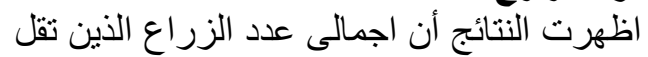

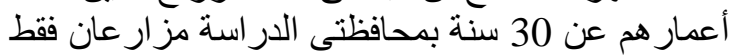

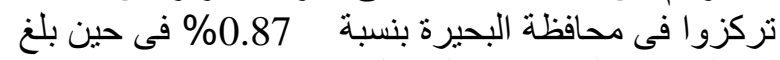

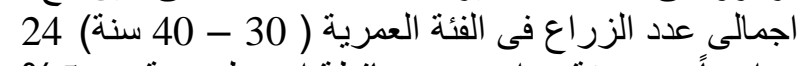

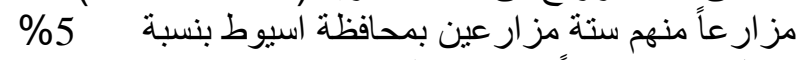

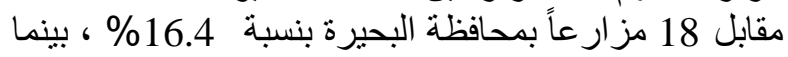

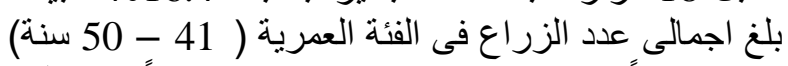
94 مزار عاً بنسبة

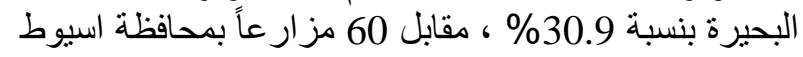

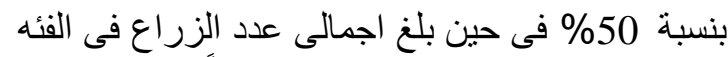

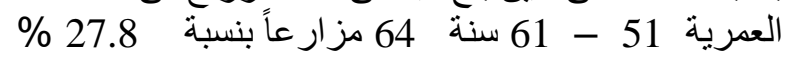

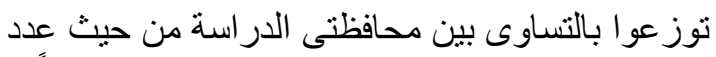

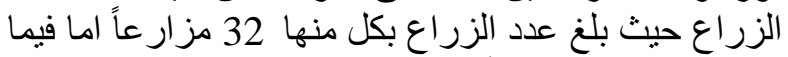

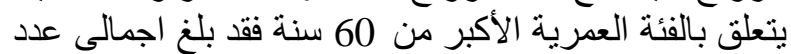

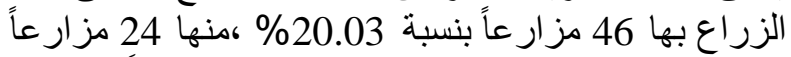
بمحافظة البحيرة بنسبة 21.8\% مقارعاً بنابل 22 مز ارعاً بمحافظة اسيوط بنسبة 18.3

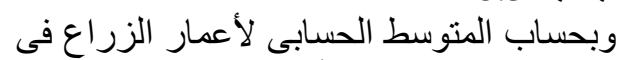

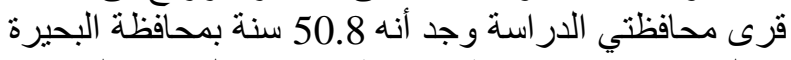

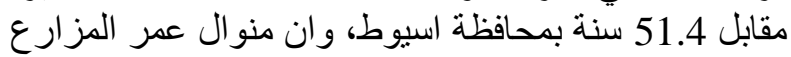

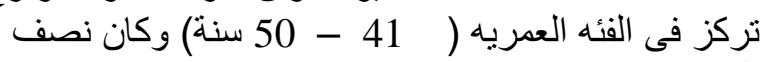
الزراع بمحافظة اسيوط بنسبة 50\% 50 تقع اعمار هم في هذه

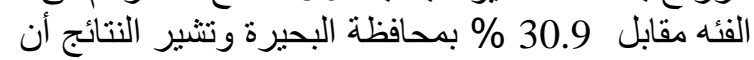

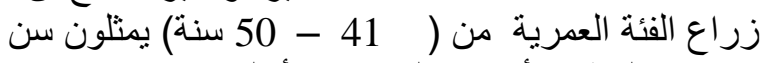

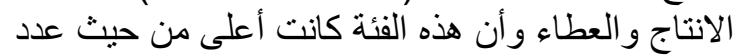

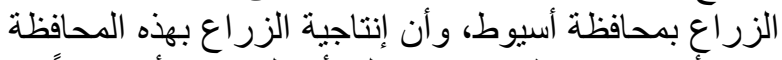

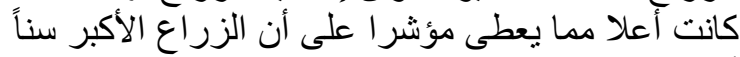

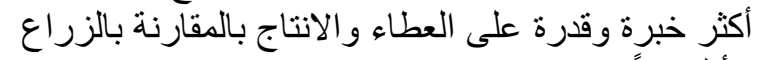
الأقل سناً.

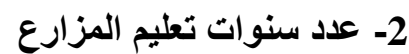
أظهرت النتائج أن اجمالى المزارع عدد الزراع الأمبين بقى 
جدول (3): توزيع أفراد العينة وفقاً للمتغيرات الاجتماعية المتعلقة بالمزارع.

\begin{tabular}{|c|c|c|c|c|c|c|}
\hline \multicolumn{2}{|c|}{ 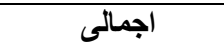 } & \multicolumn{2}{|c|}{ أسيوط } & \multicolumn{2}{|c|}{ البحيرة } & \multirow{2}{*}{ 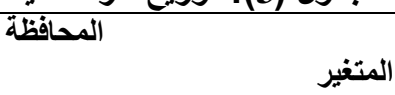 } \\
\hline$\%$ & عدد N ع & $\%$ & 2n عدد 2n & $\%$ & ع1 ع1 ( ع1 & \\
\hline 087 & 2 & - & صفر & 18 & 2 & ــــ عمر المزارع. \\
\hline 10.4 & 24 & 5.00 & 6 & 16.4 & 18 & ـ أقل من 30 - 40 سنة \\
\hline 40.9 & 94 & 50 & 60 & 30.9 & 34 & ـ أقل من 41 - 50 سه \\
\hline 27.8 & 64 & 26.7 & 32 & 29.1 & 32 & ـ أقل من 51 - 60 سنة \\
\hline \multirow[t]{2}{*}{20.03} & 46 & 18.3 & 22 & 21.8 & 24 & ـ أكثر من 60 سنة \\
\hline & & \multicolumn{2}{|c|}{51.4} & \multicolumn{2}{|c|}{50.8} & متوسط حسابي \\
\hline & & & & & & 2- عدد سنوات تعليم المزارع \\
\hline 47.8 & 110 & 45 & 54 & 50.9 & 56 & ـ ـ أقل من 12 سنة تعليم \\
\hline 28.7 & 66 & 21.7 & 26 & 36.4 & 40 & - 12 سنة تعليم \\
\hline 15.6 & 36 & 25 & 30 & 5.5 & 6 & ـ أكثر من 12 سنة تعليم \\
\hline \multirow[t]{2}{*}{7.9} & 18 & 8.3 & 10 & 7.2 & 8 & \\
\hline & & \multicolumn{2}{|c|}{5.6} & \multicolumn{2}{|c|}{3.8} & متوسط حسابي \\
\hline & & & & & & 3- الحاله الزواجيه للمزارع \\
\hline 0.87 & 2 & - & - & 1.8 & 2 & ـ اعزب اعب \\
\hline 96.5 & 222 & 95 & 114 & 98.2 & 108 & - متزوج - متز \\
\hline- & - & - & - & - & - & 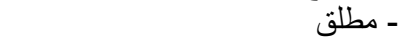 \\
\hline 2.63 & 6 & 5.00 & 6 & - & - & 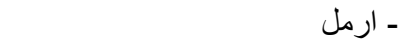 \\
\hline \multicolumn{2}{|c|}{230} & \multicolumn{2}{|c|}{120} & \multicolumn{2}{|c|}{110} & إجمالي حجم العينة \\
\hline
\end{tabular}

جدول (4) : توزيع أفراد العينة وفقاً للمتغيرات الاجتماعية المتعلقة بزوجات المزارع .

\begin{tabular}{|c|c|c|c|c|c|c|}
\hline \multicolumn{2}{|c|}{ اجمالى } & \multicolumn{2}{|c|}{ أسيوط } & \multicolumn{2}{|c|}{ البحيرة } & \multirow{2}{*}{ المتغير المحافظة } \\
\hline$\%$ & عدد N & $\%$ & عدا $2 n$ & $\%$ & ع1 عد n1 & \\
\hline $\begin{array}{c}3.5 \\
93.9 \\
2.6\end{array}$ & $\begin{array}{c}8 \\
216 \\
6\end{array}$ & $\begin{array}{c}5.00 \\
93.3 \\
1.7\end{array}$ & $\begin{array}{c}6 \\
112 \\
2\end{array}$ & $\begin{array}{c}1.8 \\
94.5 \\
3.7\end{array}$ & $\begin{array}{c}2 \\
104 \\
4\end{array}$ & 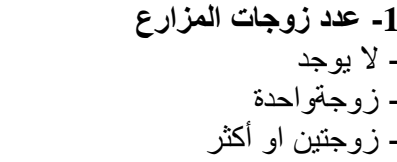 \\
\hline & & \multicolumn{2}{|c|}{120} & \multicolumn{2}{|c|}{110} & إجمالي حجم العينة \\
\hline $\begin{array}{l}75.6 \\
8.7 \\
7.8 \\
4.3\end{array}$ & $\begin{array}{l}174 \\
20 \\
18 \\
10\end{array}$ & $\begin{array}{c}71.7 \\
8.3 \\
10 \\
5.00\end{array}$ & $\begin{array}{l}86 \\
10 \\
12 \\
6\end{array}$ & $\begin{array}{l}80 \\
9.1 \\
5.5 \\
3.6\end{array}$ & $\begin{array}{c}88 \\
10 \\
6 \\
4\end{array}$ & 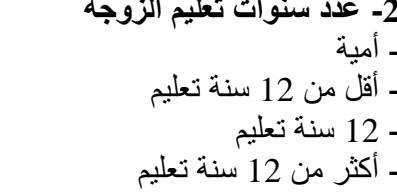 \\
\hline & & $\% 100$ & 120 & $\% 100$ & 110 & إجمالي حجم العينة \\
\hline & & \multicolumn{2}{|c|}{2.5} & \multicolumn{2}{|c|}{2} & متوسط حسابي \\
\hline
\end{tabular}




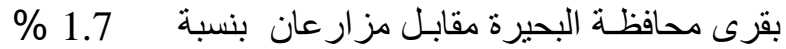

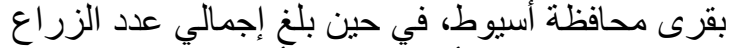

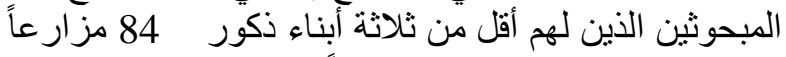
بنسبة 36.5\% منهم 46 مزارعاً بنسبة

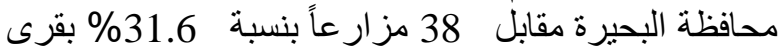

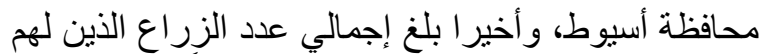

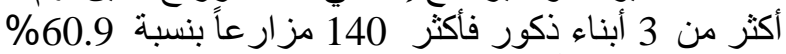

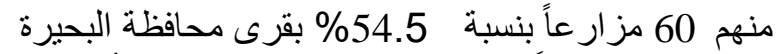

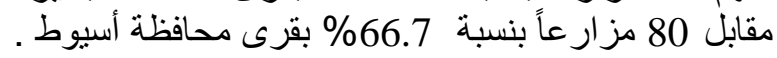

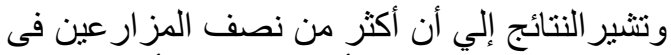

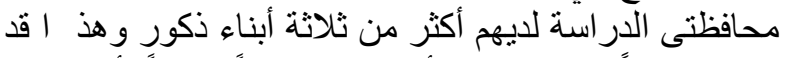

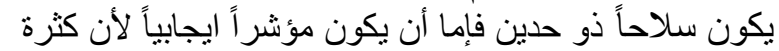

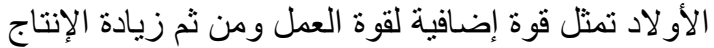

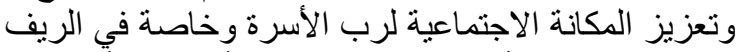

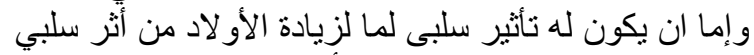

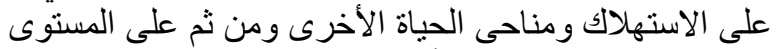

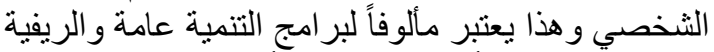

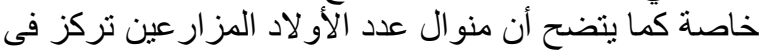

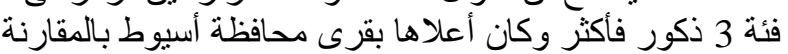

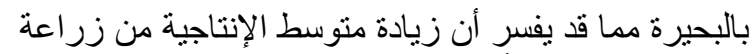

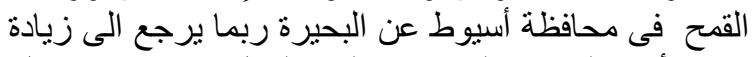

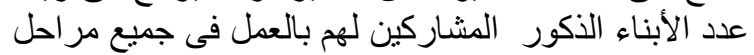

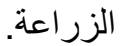

وبحساب المنوسط لعدد الأبناء الذكور في كلا المحافظتين

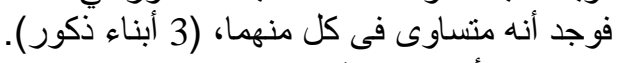
2- 2 عدد الأبناء الإناث :

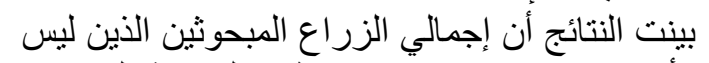

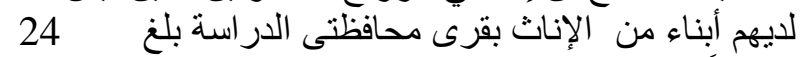

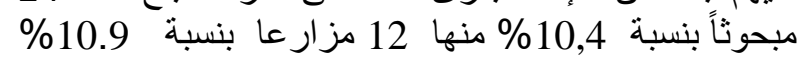

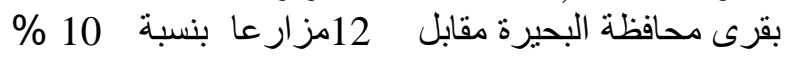

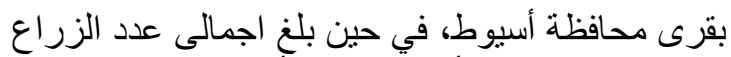

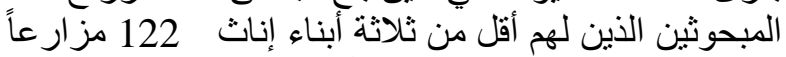

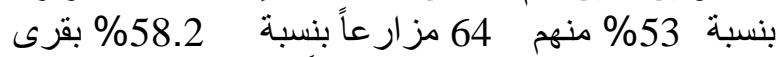

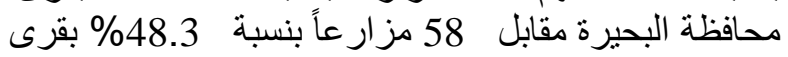

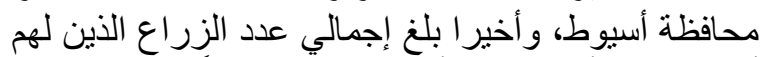

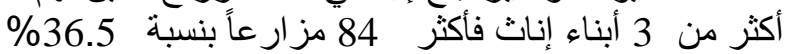

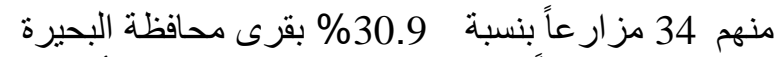
مقابل 50 مزارعاً بنسبة 34 مزبة 41.7\% بقرى محافظة أسيوط.

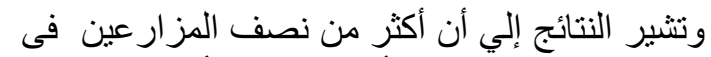

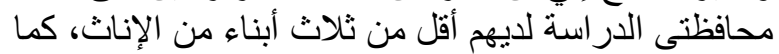

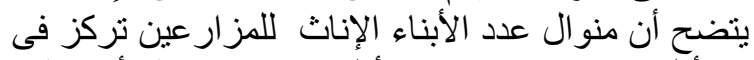

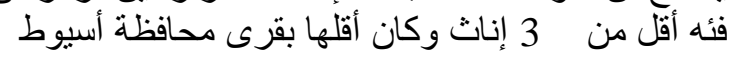

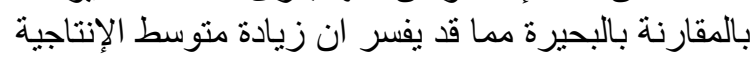

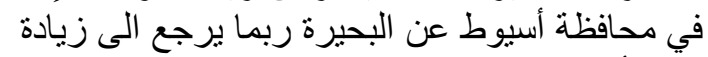

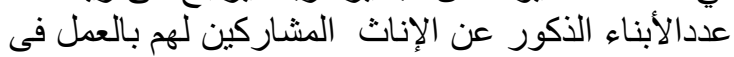

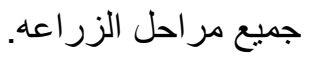

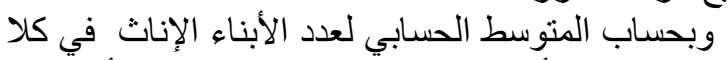

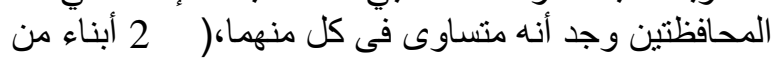

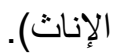

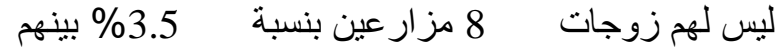

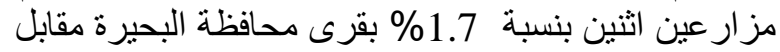

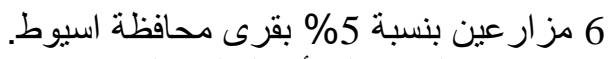

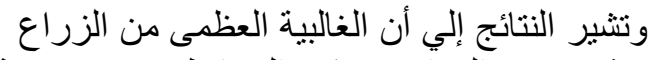

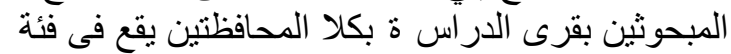

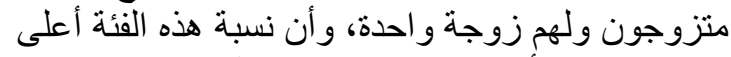

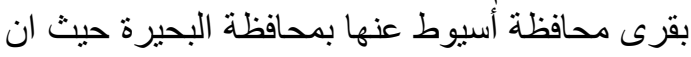

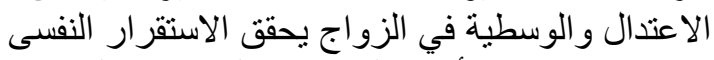

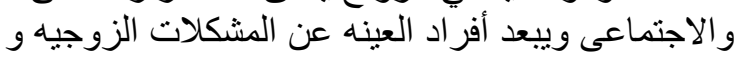

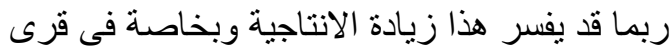
الدر اسة بمحافظة اسيوط بالمقارنه بانتاجية قرى محافظة فئنة

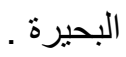

2- عدد سنوات تعليم الزوجة:

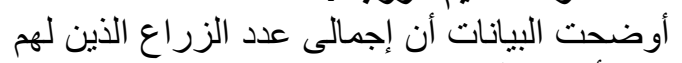

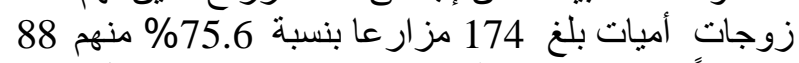
مزارعاً بقرى محافظة البحيرة بنسبة

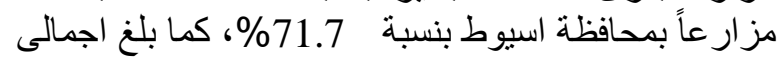

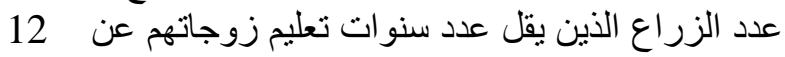
سنة تعليم 20 مزار عا بنسبة 8.7 8. حيث العدد بقرى محافظتى الدر اسة حيث بلغ بلغ عددهم 10 لكل محافظة مدروسة.

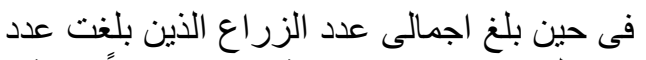

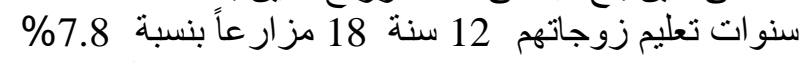

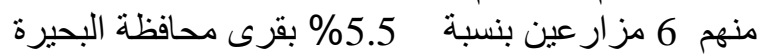

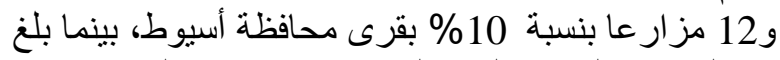

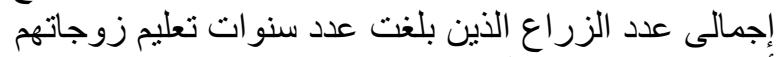

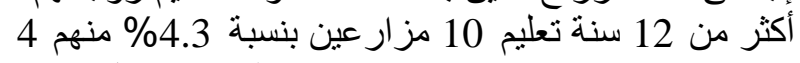

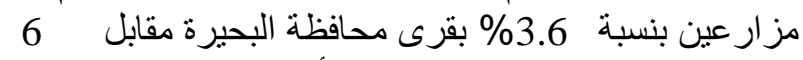

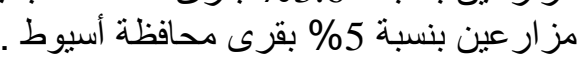

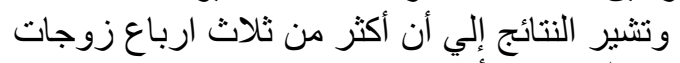

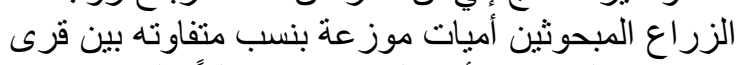

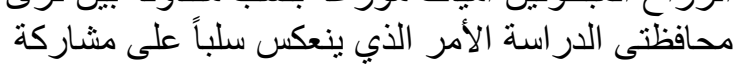

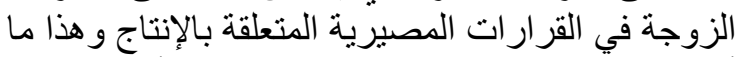

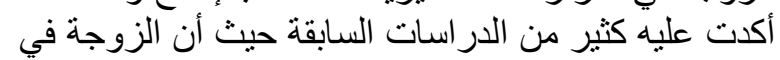

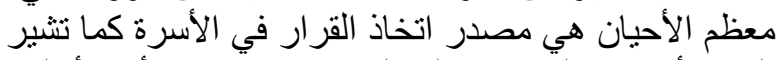

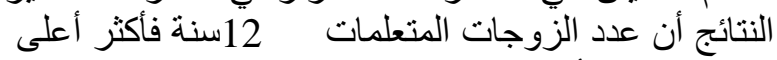

بقرى محافظة أسبوط عن مثيلتها بقرى محافظة البحات البحيرة

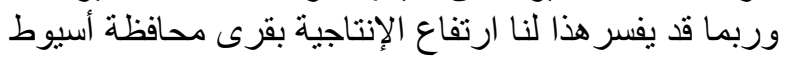
بالمقارنة بقرى محافظة البحيرة .

\section{جـ المتغير ات الاجتماعية المتعلقة بأبناء المزارع}

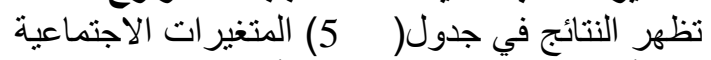

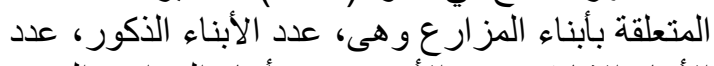

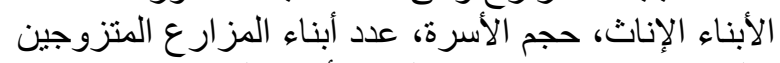

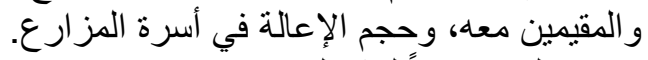
و فيما يلى عرضاً لهذه النتائج:

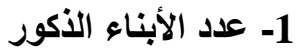

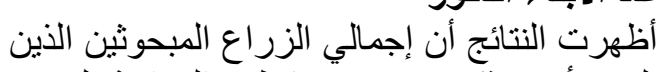

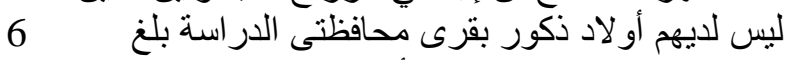

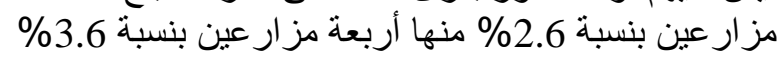


جدول (5) توزيع أفراد العينة وفقاً للمتغيرات الإجتماعية المتعلقة بابناء المزارع.

\begin{tabular}{|c|c|c|c|c|c|c|}
\hline \multicolumn{2}{|c|}{ اجمالى } & \multicolumn{2}{|c|}{ أسيوط } & \multicolumn{2}{|c|}{ البحيرة } & \multirow{2}{*}{ لمتغير } \\
\hline$\%$ & عداد N & $\%$ & عدد 2n & $\%$ & ع1 ع1 n1 & \\
\hline 26 & 6 & 17 & 2 & 36 & 4 & - 1 - ع عدد الأبناء الذكور \\
\hline 36.5 & 84 & 31.6 & 38 & 41.9 & 46 & ــ أقل من 3 أبناء ذكور \\
\hline 60.9 & 140 & 66.7 & 80 & 54.5 & 60 & -3ذكور فأكثر \\
\hline \multirow[t]{2}{*}{$\% 100$} & 230 & $\% 100$ & $\% 120$ & $\% 100$ & 110 & اجمالي حجم العينة \\
\hline & & \multicolumn{2}{|c|}{3} & \multicolumn{2}{|l|}{3} & متوسط حسابى \\
\hline & & & & & & 2- عدد أبناء الإناث \\
\hline 10.5 & 24 & 10 & 12 & 10.9 & 12 & - لا يوجد أبناء إناث \\
\hline 53 & 122 & 48.3 & 58 & 58.2 & 64 & ــ أقل من 3 أبناء إناث \\
\hline 36.5 & 84 & 41.7 & 50 & 30.9 & 34 & - 3 إناث فأكثر \\
\hline \multirow[t]{2}{*}{$\% 100$} & 230 & $\% 100$ & 120 & $\% 100$ & 110 & 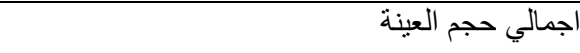 \\
\hline & & \multicolumn{2}{|c|}{2} & \multicolumn{2}{|c|}{2} & متوسط حسابي \\
\hline 8.6 & 20 & 10 & 12 & 7.3 & 8 & ــ أقل منم 5 ألفر ادة \\
\hline 65.7 & 151 & 74.2 & 89 & 56.3 & 62 & ــ من-8 أفراد \\
\hline 25.7 & 59 & 15.8 & 19 & 36.4 & 40 & ــ ـ أكثر من 8 أفراد \\
\hline \multirow[t]{2}{*}{$\% 100$} & 230 & $\% 100$ & 120 & $\% 100$ & 110 & إجمالي حجم العينة \\
\hline & & \multicolumn{2}{|c|}{2} & \multicolumn{2}{|c|}{2} & متوسط حسابى \\
\hline & & & & & & 4- عدد أبناء المزارع المتزوجين والمقيمين معه \\
\hline 69.5 & 160 & 75 & 90 & 63.6 & 70 & ل ل ل يوجد \\
\hline 26 & 60 & 23.3 & 28 & 29.1 & 32 & - 1- 2 أبناء متزوجين \\
\hline 4.5 & 10 & 1.7 & 2 & 7.3 & 8 & ـ ـ أكثر من اثنان \\
\hline$\% 100$ & 230 & $\% 100$ & 120 & $\% 100$ & 110 & إجمالي حجم العينة \\
\hline & & \multicolumn{2}{|c|}{ - } & \multicolumn{2}{|c|}{ - } & متوسط حسابي \\
\hline & & & & & & 5- حجم الاعاله فى أسرة المزارع \\
\hline $\begin{array}{l}12.6 \\
38.7\end{array}$ & $\begin{array}{l}29 \\
89\end{array}$ & $\begin{array}{l}14.2 \\
30.8\end{array}$ & $\begin{array}{ll}17 \\
37\end{array}$ & $\begin{array}{l}10.9 \\
47.3\end{array}$ & $\begin{array}{l}12 \\
52\end{array}$ & ـ فر د يعول من 3 - 4 أفر اد \\
\hline 33.9 & 78 & 38.3 & 46 & 29.1 & 32 & ـ فرد يعول من 5 - 6 أفر اد \\
\hline 14.8 & 34 & 16.7 & 20 & 12.7 & 14 & ـ فرد يعول أكثر من 6 أفراد \\
\hline \multirow[t]{2}{*}{$\% 100$} & 230 & $\% 100$ & 120 & $\% 100$ & 110 & إجمالى حجم العينة \\
\hline & & \multicolumn{2}{|c|}{4.6} & \multicolumn{2}{|c|}{4.2} & متوسط حسابي \\
\hline
\end{tabular}

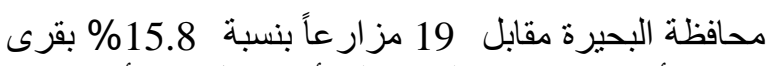

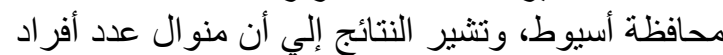

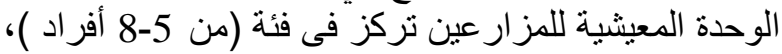
وبحساب المتوسط الحسابي لعدد أفر اد الوحدة المين المعيثية بقرى المحافظتين وجد أنهابه 8 أفر اد بقرى محافظة البر البحيرة مقابل 7 أفر اد بقرى محافظة أسيوط.

4- عدد أبناء المزارع المتزوجين والمقيل المقيمين معه:

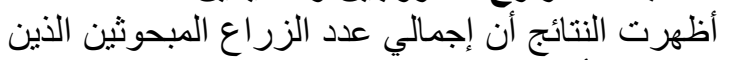

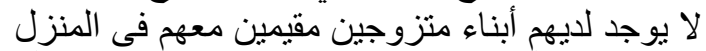

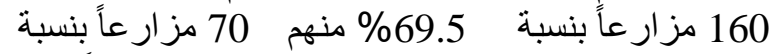

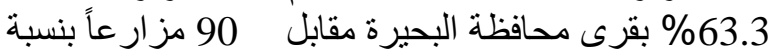

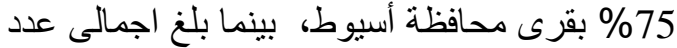
الزراع المبحوثين الذين لهم من 1 - 2 أبناء منزوجين

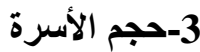

أظهرت النتائج أن اجمالى عدد الزراع الزع المبحوثين

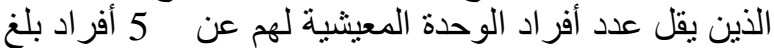

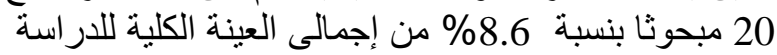

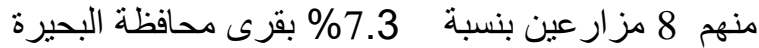
مقابل 12 مزارعاً بنسبة 10\% بقرى محافية إفظة أسيوط بينما

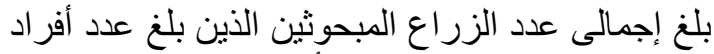

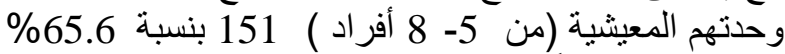

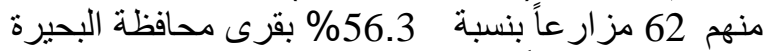

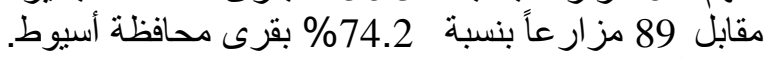

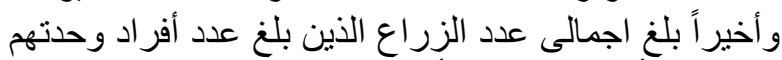

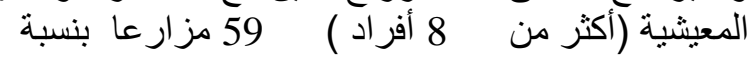

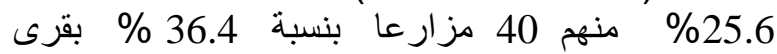


الزراع الذين استجابوا "بلا" لعدم رضاهم عن العائد المادي

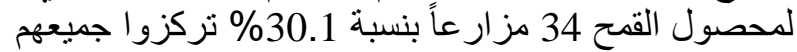
بالقرى المدروسة بمحافظة البحيرة .

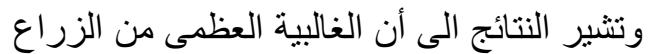

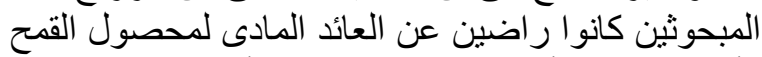

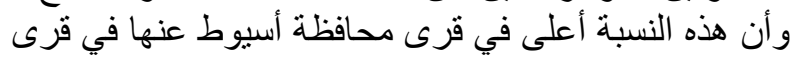
محافظة البحيرة مما قد يفسر زئية فيادة الإنتاجية في قرى في في في

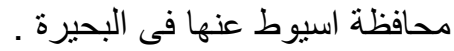

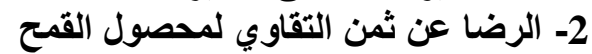

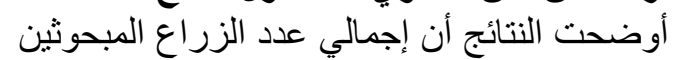

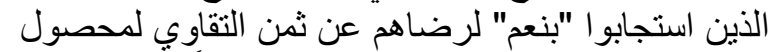
القمح بقرى محافظتى الدر اسة 180 مز ارعاً بنسبة

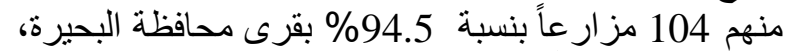

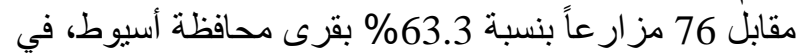

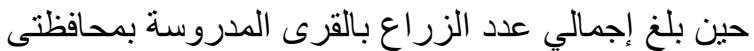

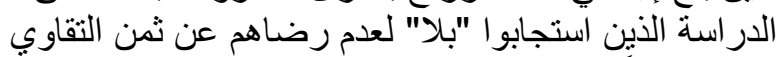

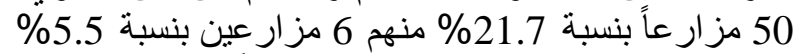

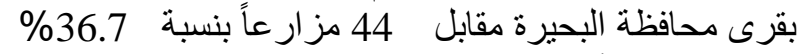

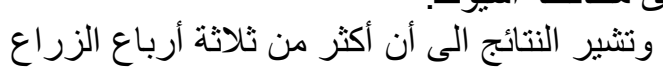

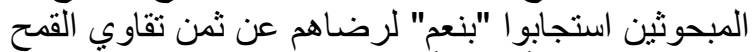

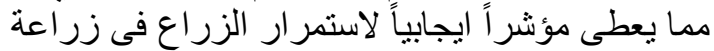

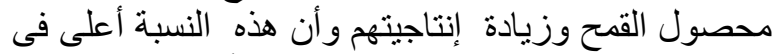

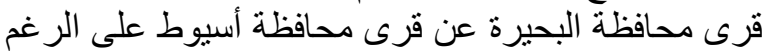
من أن إنتاجية الزراع في قرى محافظة البحيرة كانت أقل الرئل

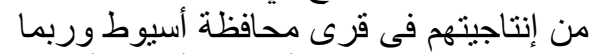

يرجع زيادة الإنتاجية بأسيوط لأسباب أخرى غير هذابوان

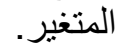

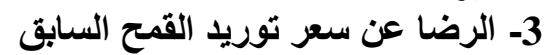

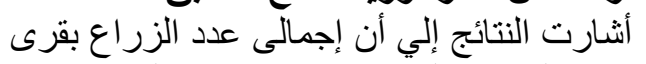

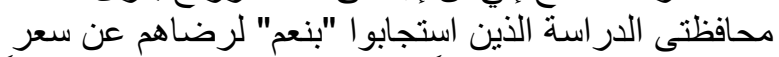

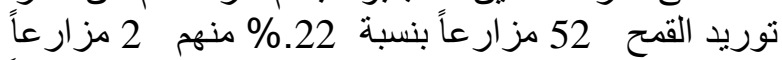

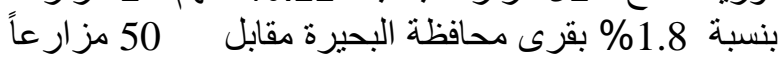

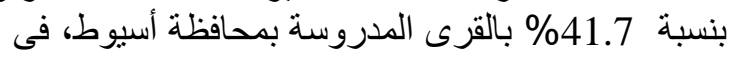

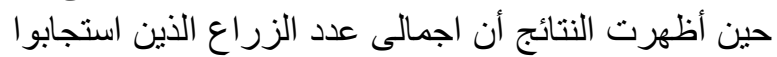

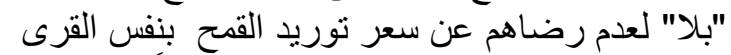

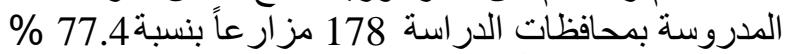

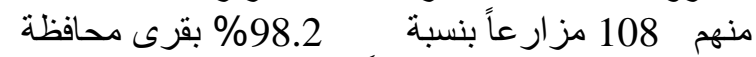
البحيرة مقابل 70 مز ارعاً بنسبة المدروسة بمحافظة اسيوط.

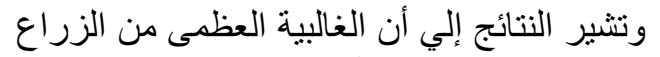

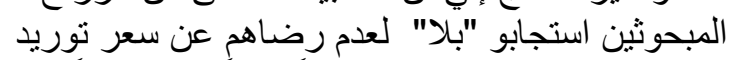

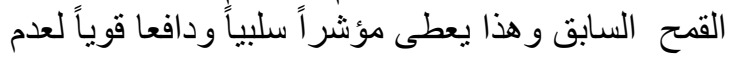

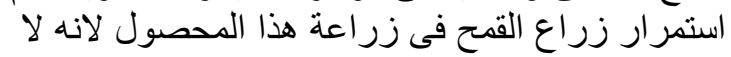

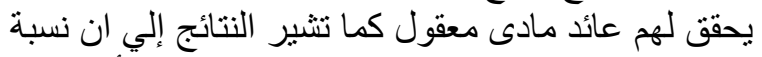

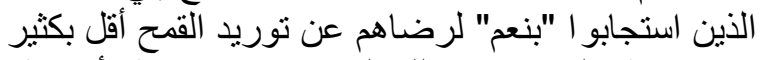

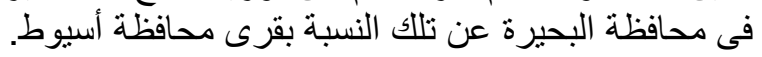

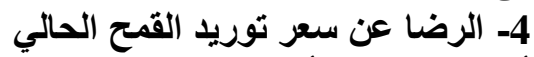
أظهرت النتائج أن إجمالى عدد الزرأَ العَ بقرى محافظتى

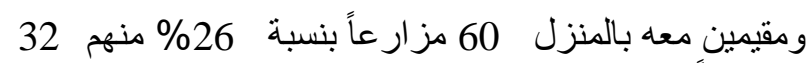

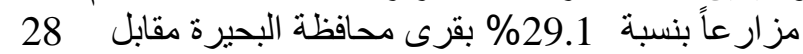

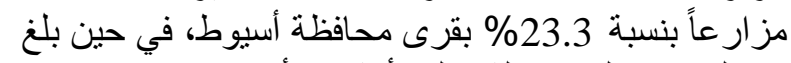

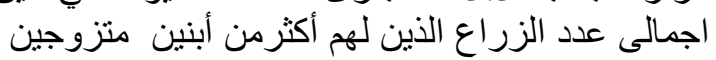

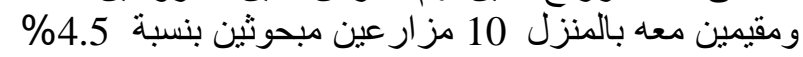

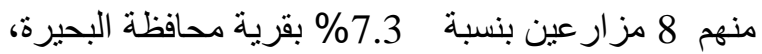

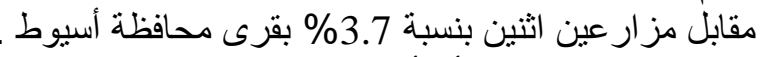

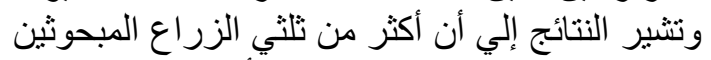

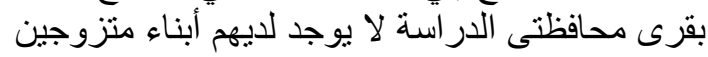

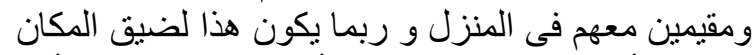

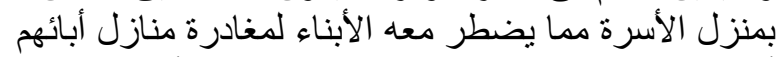

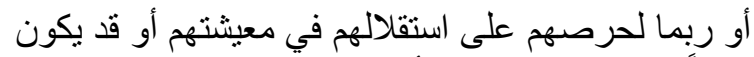

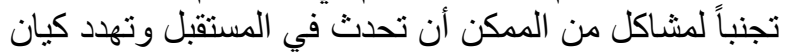

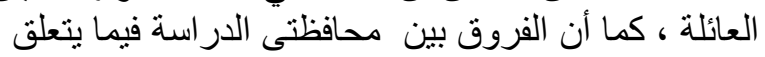

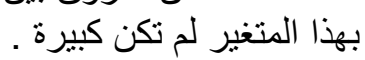

\section{5- حجم الإعالة في أسرة المزارع التئرة}

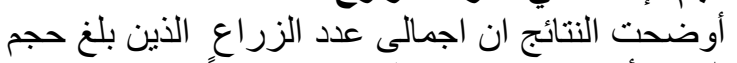

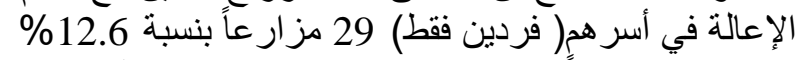

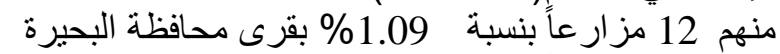

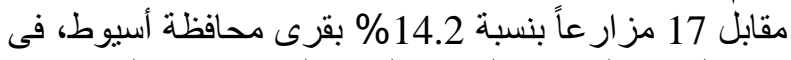
حين بلغ اجمالى عدد الزراع الزبل الذين تبلغ حجم الإعالة في

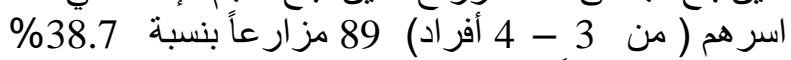

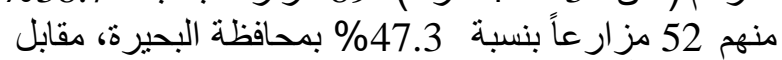

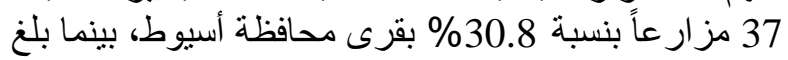

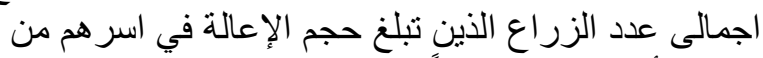

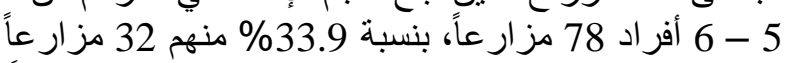

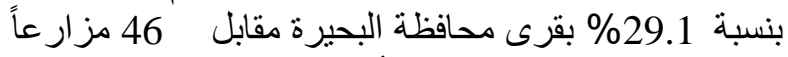

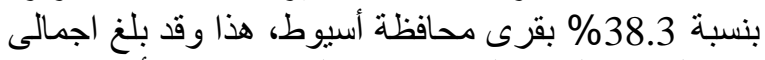
عدد الزر اع الذين تبلغ حجم الإعالة في اسر هم أكثر من

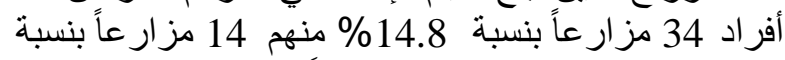

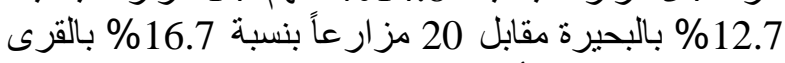

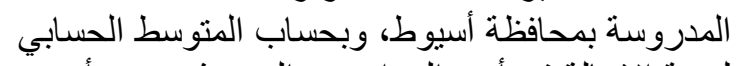

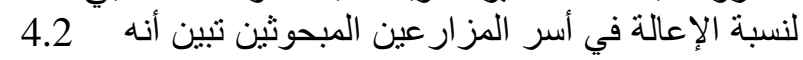
فردا فى قرى محافظة البحيرة مقابل 4.6 بقرى محافظة الإنة

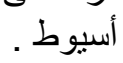

دـ المتغيرات الاجتماعية المتعلقة برضا المزارع عن زراعة محصول القمت:

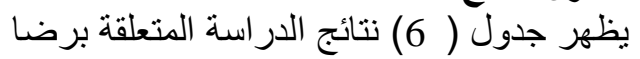

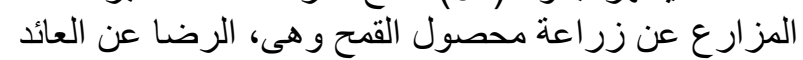

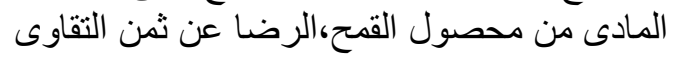

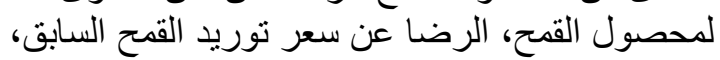

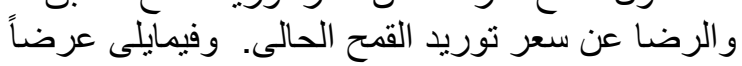

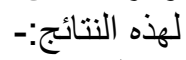

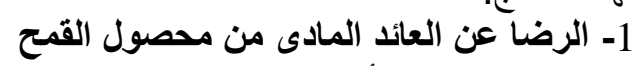

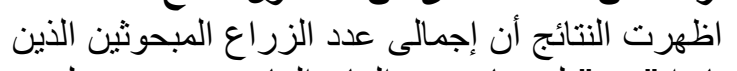

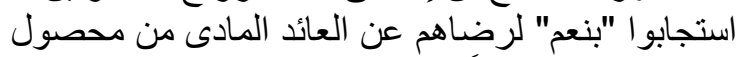

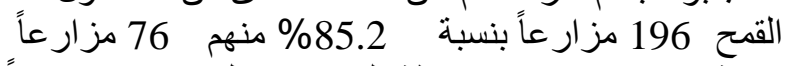
بنسبة 69.1\% بقرى محافظة البحيرة مقابل 120 مز مزارعاً بنسبة 100\% بقرى محافظة أسيوط، في حين بلغ اجمالى مقابل 


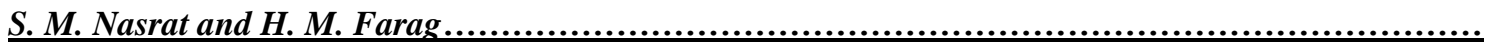

جدول(6): توزيع أفراد العينة وفقاً للمتغيرات الاجتماعية المتعلقة برضاهم عن زراعة محصول القمح القيوط

\begin{tabular}{|c|c|c|c|c|c|c|}
\hline \multicolumn{2}{|c|}{ اجمالى } & \multicolumn{2}{|c|}{ أسيوط } & \multicolumn{2}{|c|}{ البحيرة } & \multirow{2}{*}{ 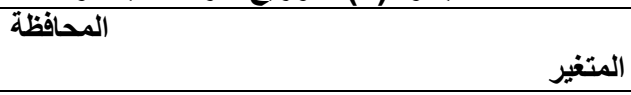 } \\
\hline$\%$ & عدد N & $\%$ & عدد & $\%$ & عدد & \\
\hline & & & & & & 1- الرضا عن العائد المادى من محصول القمح \\
\hline 85.2 & 196 & 100 & 120 & 69.1 & 76 & 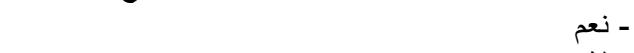 \\
\hline 14.8 & 34 & - & - & 30.9 & 34 & $\gamma-$ \\
\hline & & & & & & 2- الرضا عن ثمن التقاوى لمحصول القمح \\
\hline 78.3 & 180 & 6.3 & 76 & 94.5 & 104 & - نعم \\
\hline 21.7 & 50 & 36.7 & 44 & 5.5 & 6 & $y-$ \\
\hline & & & & & & 3-الرضا عن سعر توريد القمح السابق \\
\hline 22.6 & 52 & 41.7 & 50 & 1.8 & 2 & 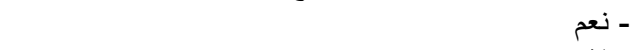 \\
\hline 77.4 & 178 & 58.3 & 70 & 98.2 & 108 & $\gamma-$ \\
\hline & & & & & & 4-الرضا عن سعر توريد القمح الحالى \\
\hline 80 & 184 & 71.7 & 86 & 89.1 & 98 & 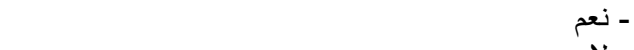 \\
\hline 20 & 46 & 28.3 & 34 & 10.9 & 12 & $\gamma-$ \\
\hline$\% 100$ & 230 & 100 & 120 & $\% 100$ & 110 & إجمالي حجم العينة \\
\hline
\end{tabular}

\begin{tabular}{|c|c|c|}
\hline \multicolumn{2}{|c|}{ قيم معامل الارتباط } & \multirow[t]{2}{*}{ المتغير } \\
\hline محافظة اسيوط & محافظة البحيرة & \\
\hline * 0.228 & ** $0.262-$ & عمر المزارع \\
\hline $0.015-$ & 0.126 & تعليم المزارع \\
\hline ** $0.262-$ & * 0.249 & عمر الزوجة \\
\hline $0.039-$ & 0.202 & تعليم الزوجة \\
\hline${ }^{* *} 0.240$ & 0.217 & عدد الأبناء الذكور \\
\hline $0.098-$ & $0.03-$ & عدد الأبناء الإناث \\
\hline${ }^{*} 0.214$ & $0.870-$ & حجم الأسرة \\
\hline 0.097 & $0.001-$ & عدد الأبناء المتزوجين و المقيمين معه \\
\hline 0.127 & $0.013-$ & حجم الإعالة في أسرة المزارع \\
\hline
\end{tabular}

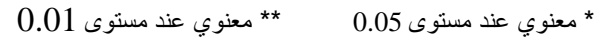

جدول (8) : العلاقة بين انتاجية فان القمح و المتغيرات الاجتماعية الاسمية المدروسة.

\begin{tabular}{|c|c|c|c|c|}
\hline \multicolumn{4}{|c|}{ قيم مربع كاي } & \multirow{3}{*}{ 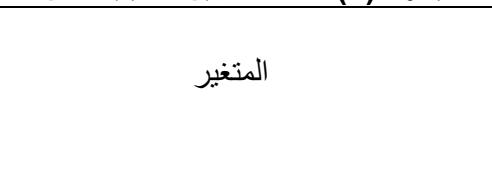 } \\
\hline \multicolumn{2}{|c|}{ اسيوط } & \multicolumn{2}{|c|}{ البحيرة } & \\
\hline درجات الحرية & القيمة & درجات الحرية & 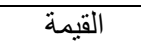 & \\
\hline 7 & صفر & 8 & **33.279 & الرضا عن العائد المادي من محصول القمح \\
\hline 7 & ** 17 & 8 & 4.553 & الرضا عن ثمن الثقاوي \\
\hline 7 & ${ }^{*} 15$ & 8 & $* * 28.765$ & الرضا عن سعر توريد القمح السابق \\
\hline 7 & *12 & 8 & $* * 22.751$ & الرضا عن توريد سعر القمح الحالي \\
\hline & & & & 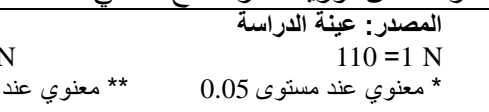 \\
\hline
\end{tabular}




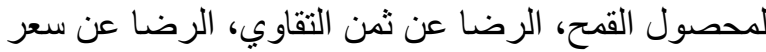

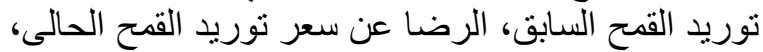

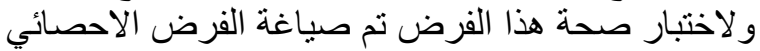

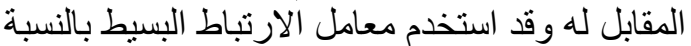

لمتغير ات الدر اسة المستمرة ( Interval) و استخدم اختبار الأبنار مربع كاى بالنسبة لمتغيرات الدئرة الداتة الإسمية (Nominal) المتغير ات التي لم تظهر اي تباينات في استجاباتها

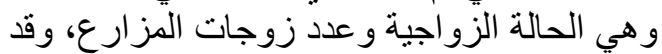

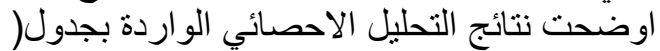

بالنسبة: لمحافظة البحيرة

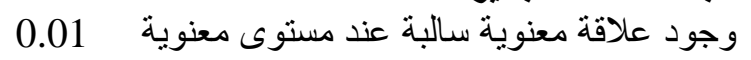

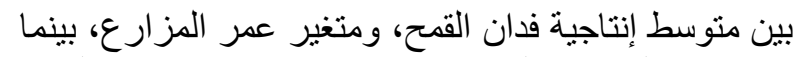

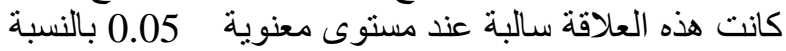
لمتغير عمر الزوجة ، ولم تثبت معنوية العلاقة الإرتباطية

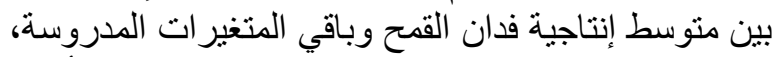

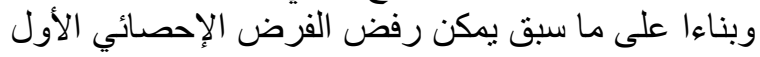

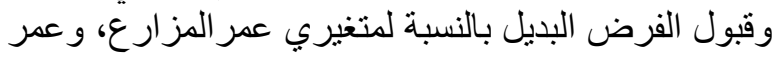

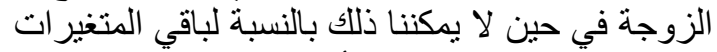

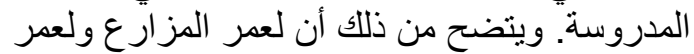

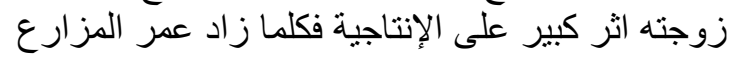

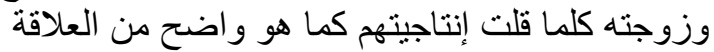
العكسية للارتباط.

بالنسبة لمحافظة أسيوط

وجود علاقة معنوية سالبة عن مسنوى معنوية 0.01

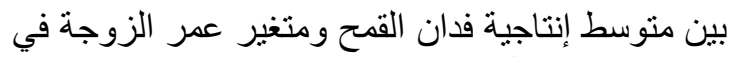

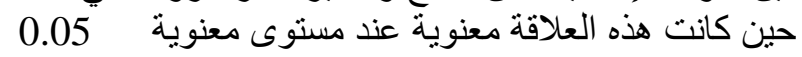

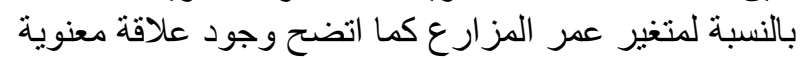

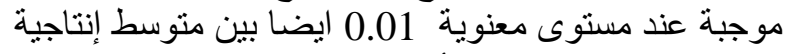

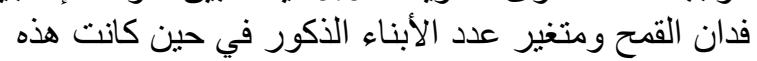

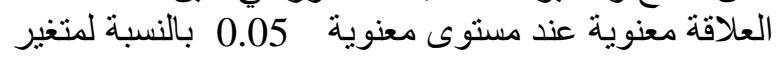

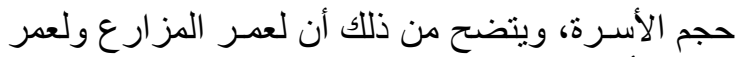

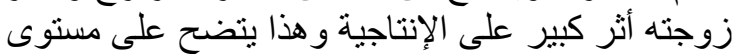

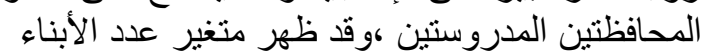

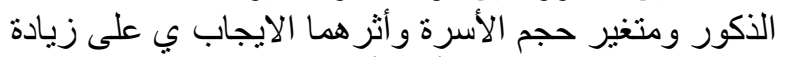

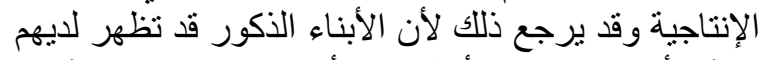

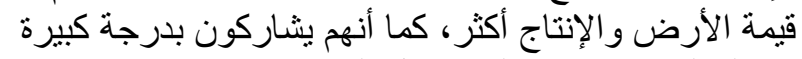

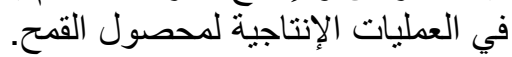

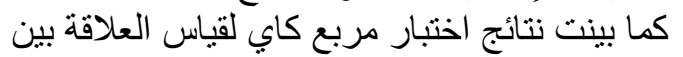

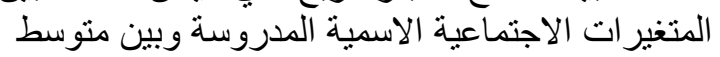

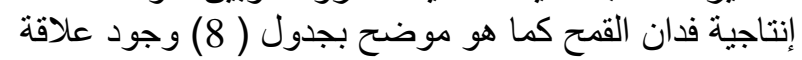

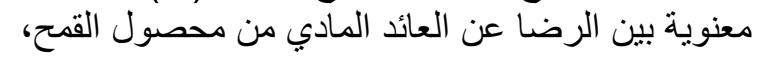

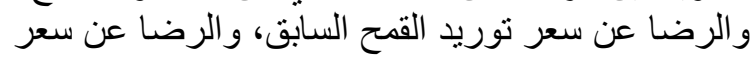

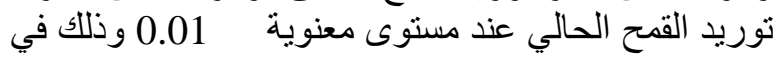

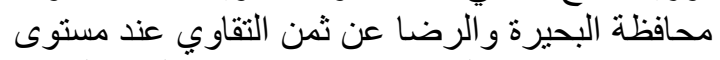

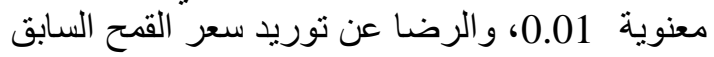

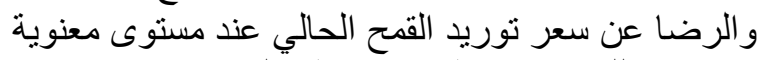

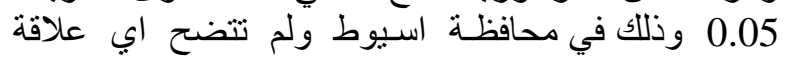

الدر اسة الذين استجابو ا "بنعم" لرضاهم عن سعر توريد

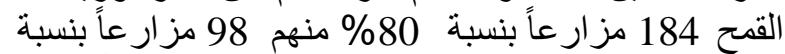

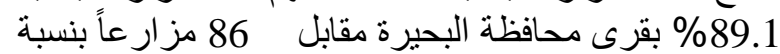

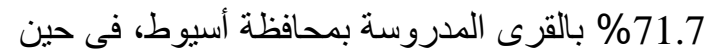

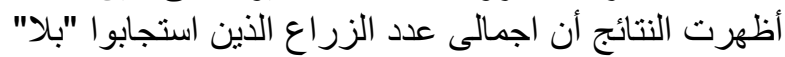

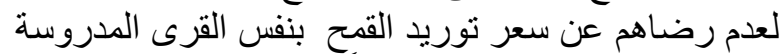

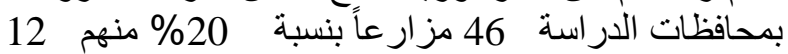

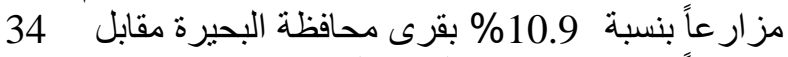
مز ارعاً بنسبة 28.3\% بارية بالقرى المدروسة بمحافظة اسيوط.

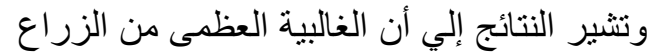

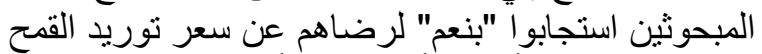

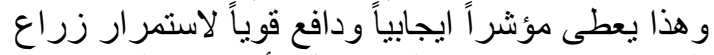

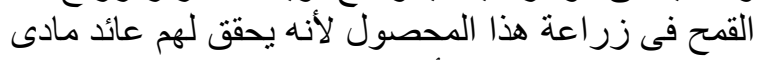

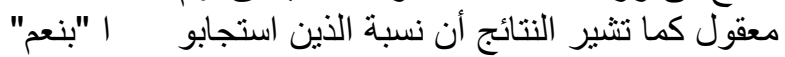

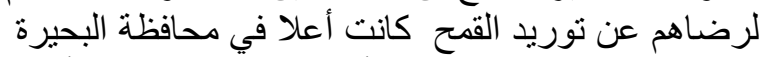

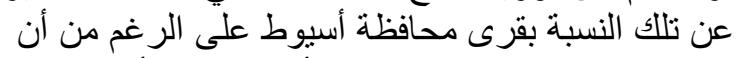

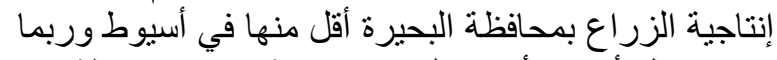

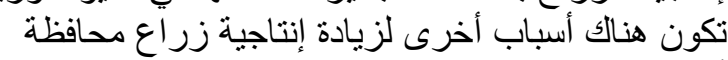
أسيوط عنها فى البحيرة بخلاف أبرى رضادم إنتاجة زن سعر توريد 3- النتائج ومناقشتها 1-3ـ الفروق بين انتاجية الفدان لمزارعي القمح بمحافظتي الاراسة بن الفز

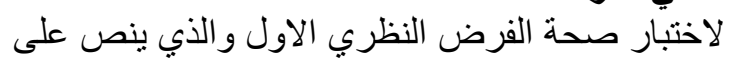

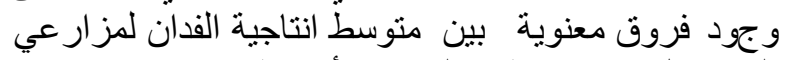

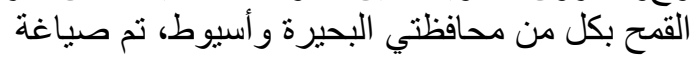

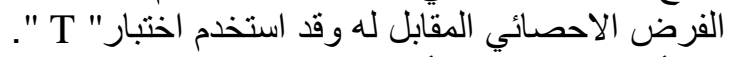

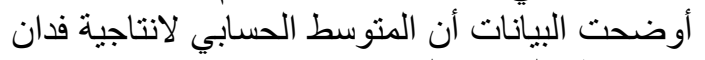

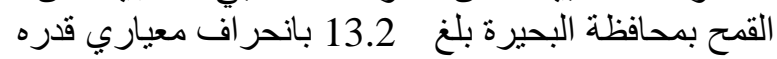

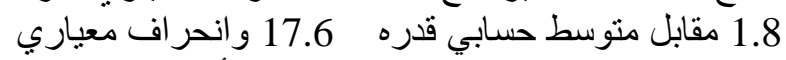

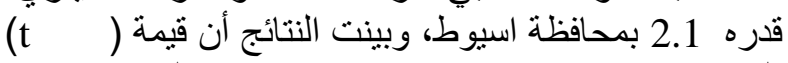

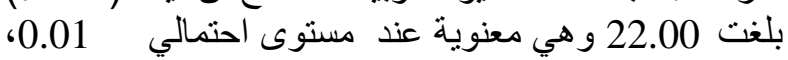

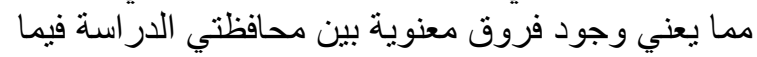

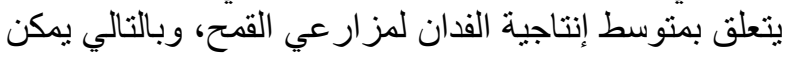

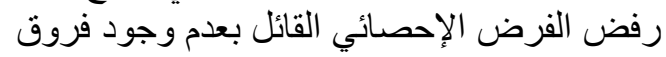

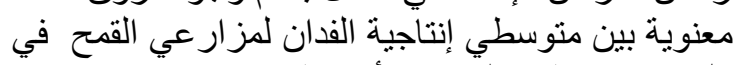

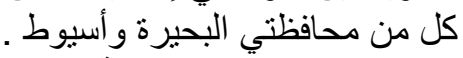
2-3. المتغيرات الاجتماعية المحددةلانتاج محصول القمح بمحافظتي الاراسة

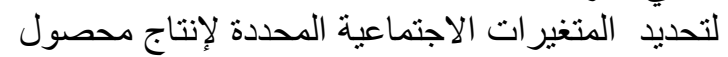

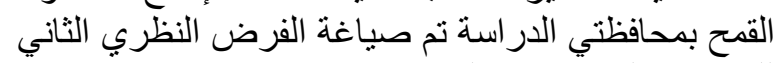

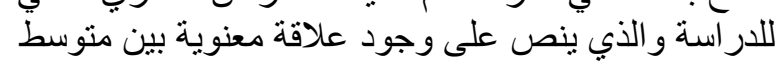

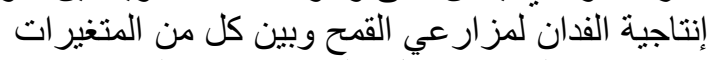

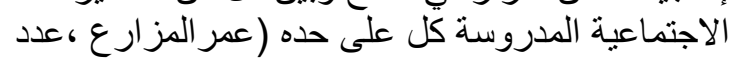

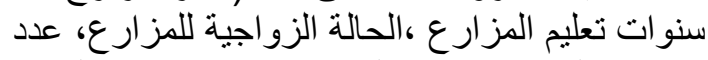

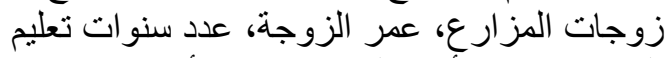

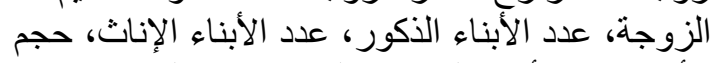

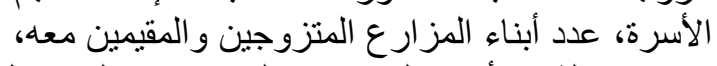
حجم الإعالة في أسرة المزارعة الرعار الرضئ عن العائد المادي 


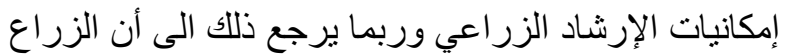

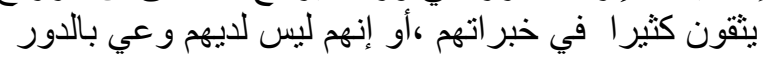

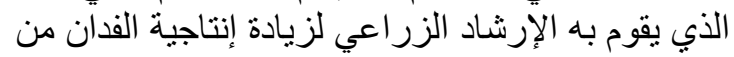

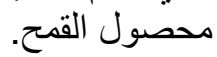

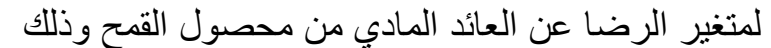
لان جميع أفر اد العينة اقروا برضاهم عن العائد المّادي من من

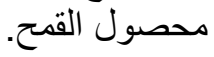

جدول رقم (9): توزيع الزراع المبحوثين وفقاً لمقترحاتهم بثأن زيادة انتاجيهم من محصول القمح

\begin{tabular}{|c|c|c|c|c|c|c|}
\hline \multicolumn{2}{|c|}{ اجمالى } & \multicolumn{2}{|c|}{ أسيوط } & \multicolumn{2}{|c|}{ 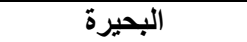 } & \multirow{2}{*}{ 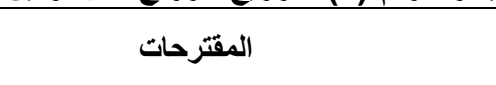 } \\
\hline$\%$ & عدد N ( ع & $\%$ & 2n عدد 2n (2) - (2) & $\%$ & ع1 ع1 ( عد & \\
\hline 9.6 & 22 & 11.5 & 15 & 6.4 & 7 & 1- مستلزمات الانتاج باسعار مناسبة \\
\hline 25.6 & 59 & 18.3 & 22 & 37.6 & 37 & 2- توفير التقاوى باسعار مناسبه. \\
\hline 11.7 & 27 & 16.7 & 20 & 6.4 & 7 & 3- توفير اصناف ذو انتاجيه غاليه. \\
\hline - & - & - & - & - & - & 4- مجانيه او دعم التسويه بالليزر . \\
\hline 1.3 & 3 & - & - & 2.7 & 3 & 5- توفير مياة الرى فى مو اعيد مناسبه. \\
\hline 31.7 & 73 & 25 & 30 & 39 & 43 & 6- توفير الاسمدة باسعار معقوله. \\
\hline 10 & 23 & 16.7 & 20 & 2.7 & 3 & 7- توفير الاسمدة الزر اعيه. \\
\hline 4.3 & 10 & - & - & 9.9 & 10 & 8- توفير مبيدات الحشائش ودعمها. \\
\hline 0.87 & 2 & - & - & 1.8 & 2 & 9- زيادة امكانيه الارشاد الزر اعى. \\
\hline 10.4 & 24 & 4.2 & 5 & 17.3 & 19 & 10- زيادة سعر التوريد الى 600 جنية. \\
\hline 2.2 & 5 & - & - & 4.5 & 5 & 11- توفير اعلاف الحيوانات باسعار مناسبه. \\
\hline 12.6 & 29 & 20.8 & 25 & 3.6 & 4 & 12- عقد ندوات للتو عيه بالقمح. \\
\hline 8.7 & 20 & 12.5 & 15 & 4.5 & 5 & 13- عودة الدورة الزر اعية. \\
\hline
\end{tabular}

\section{التوصيات}

بناءاً على نتائج الدراسة السابقة يمكن التوصية إلى الجهات التهات

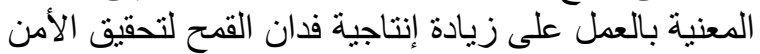

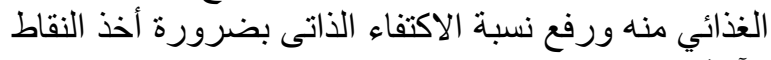

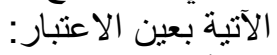

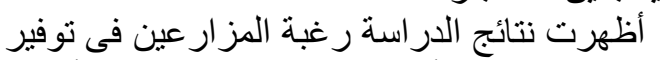

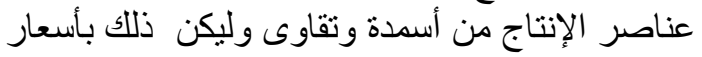

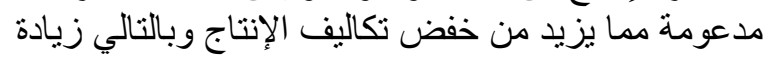

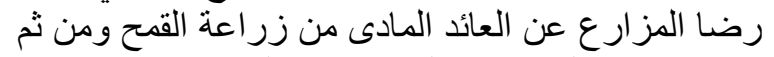

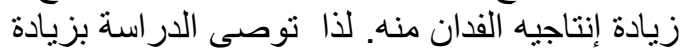

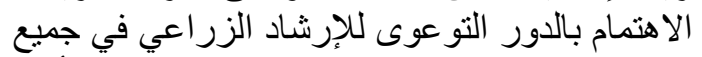

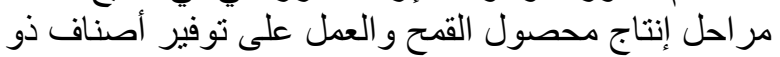

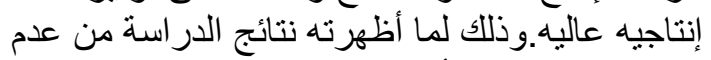

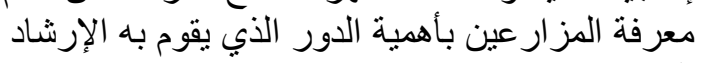

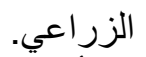
أظهرئ النتائج وجود علاقة بين رضا المزار الروع وبين

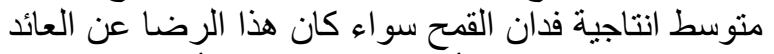

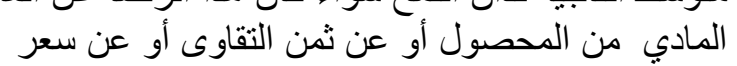

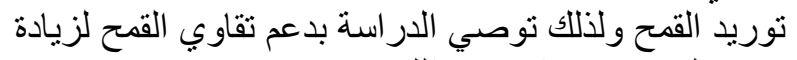

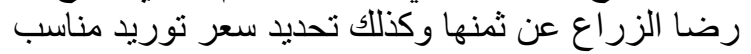

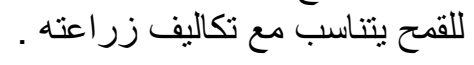

\section{4- المراجع}

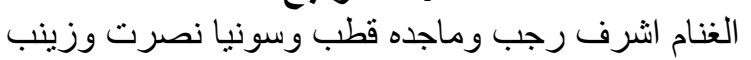

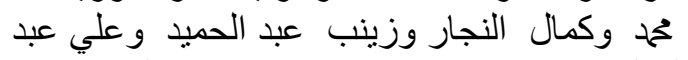

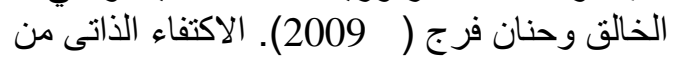

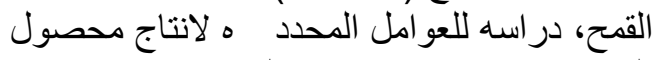

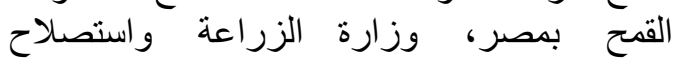

ونستنتج مما سبق أن من العوامل الاجتماعية المحددة

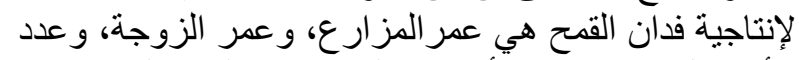

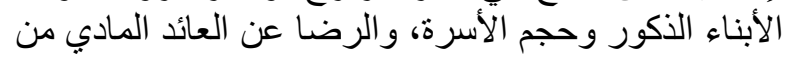

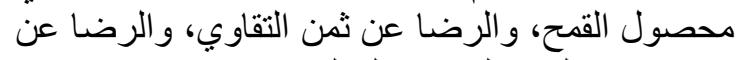

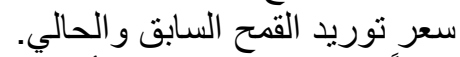
رابعاً: مقترحات الزراع بشأن زيادة النتاجئ التهم من محصول القمح أظهرت نتائج جدول رقم ( 9) ان هنالك ثلاث عشرة

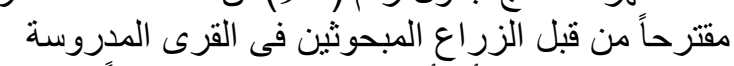

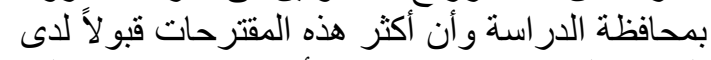

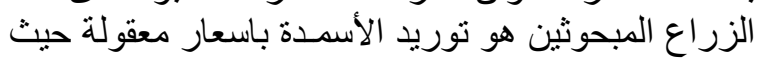

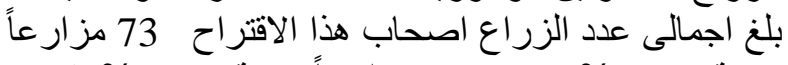

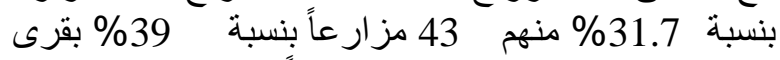
محافظة البحيرة، مقابل 3: 30 مزارعاً بنسبة

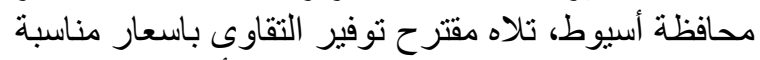

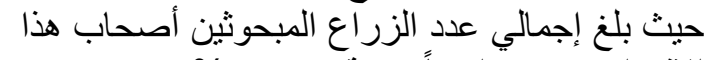

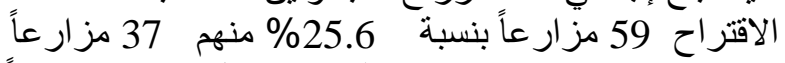

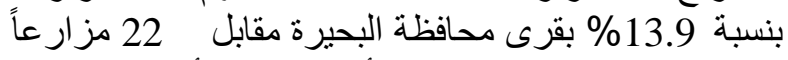
بنسبة 18.3\% بقرى محافظة أسيوط وكان البحرة أقل هذه

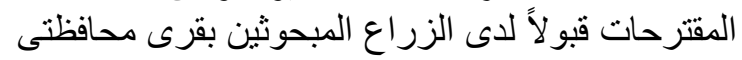

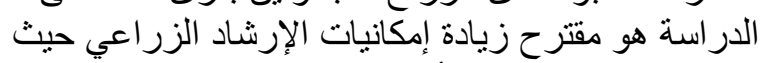

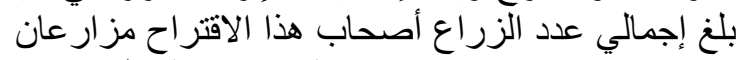

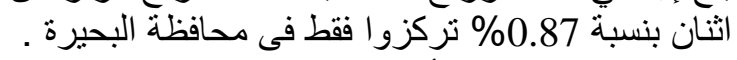

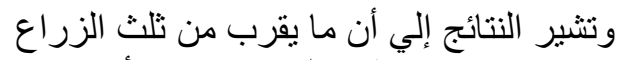

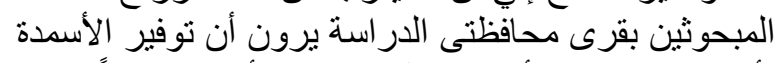

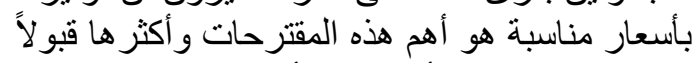

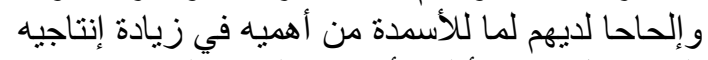

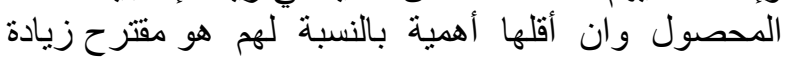




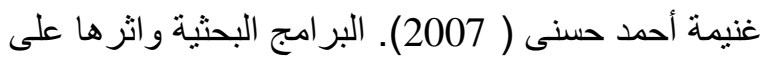

$$
\begin{aligned}
& \text { انتاج المحاصيل الحقلية، المجلة الزر الئة العية، العدد } \\
& 585 \text { (أغسطس). } \\
& \text { مجلس الوزراء، مركز المعلومات ودعم اتخاذ التواذ القرار }
\end{aligned}
$$

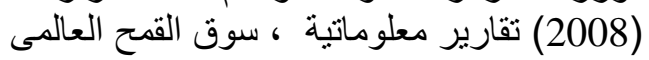

$$
\begin{aligned}
& \text { إلى اين، السنة الثانية، العدد } 14 \text { فبر اير. }
\end{aligned}
$$

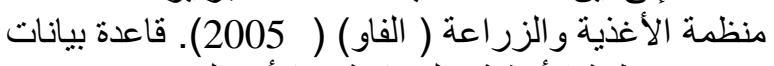

$$
\begin{aligned}
& \text { منظمة الأغذية و الزر اعة ـ الأمم المتحدة. }
\end{aligned}
$$

$$
\begin{aligned}
& \text { الأراضي، مركز البحوث الزر اعية، معهد بحوث الإرشاد }
\end{aligned}
$$

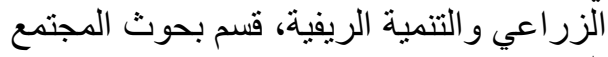

$$
\begin{aligned}
& \text { الريفى. - الزي } \\
& \text { عمارة رضا عباس ( 2002). أثر سياسة تحرير الاقتصاد التهرية }
\end{aligned}
$$

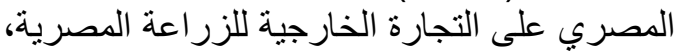

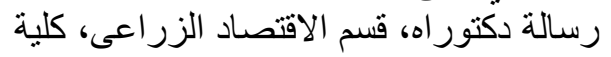

$$
\begin{aligned}
& \text { الزر اعه، جامعة عين شمس. } \\
& \text { عماره عزة إبر اهيم ( اعة 2003). سياسة الأمن الغذائي، } \\
& \text { المؤتمر الحادي عشر للاقتصاديين الزراعيين الاعن الغذي، } 24
\end{aligned}
$$

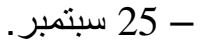

